\title{
biomolecules
}

ISSN 2218-273X

www.mdpi.com/journal/biomolecules/

Review

\section{Comparative Studies of Vertebrate Beta Integrin Genes and Proteins: Ancient Genes in Vertebrate Evolution}

\author{
Roger S. Holmes ${ }^{1} *$ and Ujjwal K. Rout ${ }^{2}$ \\ 1 School of Biomolecular and Physical Sciences, Griffith University, Nathan, 4111QLD, Australia \\ 2 Department of Surgery, University of Mississippi Medical Center, Jackson, MS 38677, USA; \\ E-Mail: urout@umc.edu
}

* Author to whom correspondence should be addressed; E-Mail: r.holmes@griffith.edu.au; Tel.: +61-7-3348-2834.

Received: 18 July 2011; in revised form: 14 August 2011 / Accepted: 15 August 2011 /

Published: 23 August 2011

\begin{abstract}
Intregins are heterodimeric $\alpha$ - and $\beta$-subunit containing membrane receptor proteins which serve various cell adhesion roles in tissue repair, hemostasis, immune response, embryogenesis and metastasis. At least $18 \alpha$ - (ITA or ITGA) and $8 \beta$-integrin subunits (ITB or ITGB) are encoded on mammalian genomes. Comparative ITB amino acid sequences and protein structures and $I T B$ gene locations were examined using data from several vertebrate genome projects. Vertebrate ITB genes usually contained 13-16 coding exons and encoded protein subunits with $\sim 800$ amino acids, whereas vertebrate ITB4 genes contained 36-39 coding exons and encoded larger proteins with 1800 amino acids. The ITB sequences exhibited several conserved domains including signal peptide, extracellular $\beta$-integrin, $\beta$-tail domain and integrin $\beta$-cytoplasmic domains. Sequence alignments of the integrin $\beta$-cytoplasmic domains revealed highly conserved regions possibly for performing essential functions and its maintenance during vertebrate evolution. With the exception of the human ITB8 sequence, the other ITB sequences shared a predicted 19 residue $\alpha$-helix for this region. Potential sites for regulating human ITB gene expression were identified which included $\mathrm{CpG}$ islands, transcription factor binding sites and microRNA binding sites within the 3'-UTR of human ITB genes. Phylogenetic analyses examined the relationships of vertebrate beta-integrin genes which were consistent with four major groups: 1: ITB1, ITB2, ITB7; 2: ITB3, ITB5, ITB6; 3: ITB4; and 4: ITB8 and a common evolutionary origin from an ancestral gene, prior to the appearance of fish during vertebrate evolution. The phylogenetic analyses revealed that
\end{abstract}


ITB4 is the most likely primordial form of the vertebrate $\beta$ integrin subunit encoding genes, that is the only $\beta$ subunit expressed as a constituent of the sole integrin receptor ' $\alpha 6 \beta 4$ ' in the hemidesmosomes of unicellular organisms.

Keywords: vertebrates; amino acid sequence; $\beta$-integrin; evolution; gene duplication

\section{Introduction}

Cell surface integrin receptors regulate cell-cell and cell-extra cellular matrix (ECM) interactions and are involved in mediating all known basic cellular processes (proliferation, migration, differentiation and death) in the body. Precise regulations of these cellular processes by a wide range of integrin receptors are witnessed in cells during development and later in life [1-7]. Disturbance of integrin function/s lead to suboptimal organogenesis in rodent animal models [5-8] and disease states in human populations [9-10].

An integrin receptor is a heterodimer consisting of an $\alpha$ and a $\beta$ subunit, each containing extracellular, transmembrane and cytosolic domains. The extracellular domains of receptor subunits bind with the ECM proteins (such as fibronectin, laminin and collagen) and the cytosolic domains of $\beta$ subunits interact with kinases (focal adhesion kinase and Src kinase), adaptor molecules (such as talin and kindlin) and the cytoskeleton (actin and microtubules) [5,11-12]. These interactions facilitate the 'outside-in' and the 'inside-out' signaling across the cell membrane by the integrin heterodimers [12-14].

While the evolutionary path of integrins in development and maintenance of cellular process are intensive areas of investigation [15-17], the evolution of different integrin subunits encoded within the vertebrate genomes remains to be fully elucidated. This knowledge is necessary for understanding the integrin receptors and the evolution of cellular functions that are coordinated by these versatile receptors. Evolution of integrin genes dates back to the time of transition of unicellular life forms into multicellular organisms [18-19]. It is known that the integrin-mediated adhesion system existed in the single celled Amastigomonas (Phylum Apusozoa), possibly for the purpose of attachment with the basal lamina, a transition towards sedentary life and multicellularity [19]. In vertebrates, a phylum that includes $\sim 53,000$ species, the genes coding integrins are identified as early as in fishes (Actinopterygians) that evolved about 450 millions of years ago (Mya) [20]. Here we report the gene structures and amino acid sequences for vertebrate $\beta$-integrin encoding genes (ITB) and proteins (ITB), respectively, as well as their phylogenetic and evolutionary relationships. Potential regulatory sites for several human ITB genes, predicted secondary structures of signal peptides and cytoplasmic domains and tissue specific expression for mammalian ITB genes are also discussed in terms of their homology and evolution.

\section{Results and Discussion}

\subsection{Vertebrate ITB Gene Locations and Exonic Structures}

Table 1 summarizes the locations and predicted structures for vertebrate ITB genes based upon BLAT interrogations of several vertebrate genomes using the reported sequences for human ITB1 [21-24], 
ITB2 [25-27]; ITB3 [28-31]; ITB4 [32-34]; ITB5 [35-37]; ITB6 [38-40]; ITB7 [41-42]; and ITB8 [43-44] and the University of California Santa Cruz (UCSC) Genome Browser [45]. The predicted vertebrate ITB genes predominantly contained 13-16 coding exons, with the exception of vertebrate ITB4 genes which exhibited 36 (opossum ITB8) to 39 coding exons and encoded larger ITB protein subunits ( 1,800 amino acids) as compared with other ITB subunits which contained $\sim 800$ amino acids in sequence (Table 1). ITB genes were separately located on vertebrate chromosomes for each of the genomes examined in comparison with other gene families which may be clustered on a single chromosome (e.g., the alcohol dehydrogenase $(A D H)$ gene family) [46] or a small number of chromosomes such as the lactate dehydrogenase $(L D H)$ gene family [47].

\subsection{Vertebrate ITB Signal Peptides and Domain Structures}

Application of the SignalP 3.0 server predicted a standard length of signal peptides for ITB1 (20 aa), ITB2 (22 aa), ITB3 (26 aa), ITB4 (27 aa), ITB5 (24 aa), ITB6 (21 aa) and ITB7 (19 aa) subunits except for a long signal sequence (42 aa) for the smallest size integrin isoform ITB8. Although, the server provided a distinct cleavage site for signal peptides in all human ITB forms, a recent study has shown that the signal peptide of the $\beta 2$ integrin subunit in ruminants containing cleavage inhibition glutamine (Q) was not processed [48]. Not much is known about the signal peptide processing of integrins; however, human ITB1 and ITB2 integrin subunits contain cleavage inhibiting ' $Q$ ' at the predicted cleavage sites (data not shown). Domain annotation of signal sequences of ITB genes predicted a central helical domain with an anterior and a posterior coiled motifs in ITB1, ITB2, ITB3, ITB5, ITB6 and ITB7 subunits. The signal peptide for ITB8, however, consisted of two central helical motifs separated by a coiled motif and two additional coiled motifs at the $\mathrm{N}$ and $\mathrm{C}$ terminal ends of the signal peptide. The predicted signal peptide sequences from different ITB subunits showed little evidence of sequence similarity (data not shown) that is not uncommon for signal peptides [49]. The lack of identity amongst the primary structures of signal sequences of different ITB subunits and the similarity amongst the secondary structures (a central hydrophobic core with coiled motifs at the ends) implies that these secondary structures of signal sequences are indispensible conformations for the insertion of the $\mathrm{N}$-terminal ends of beta-subunits into the cell membrane. The reason for the very long signal sequence and two hydrophobic motifs in the ITB8 structure is unclear although it is possible that an additional hydrophobic motif may enhance the processing and translocation of ITB8 into the lipid bilayer [50-51].

Figure 1 illustrates the predicted domain structures for ITB2 and ITB4, with the former representing the domain structures for ITB1, ITB3, ITB5, ITB6, ITB7 and ITB8 [52] including the $N$-signal peptide previously described (residues 1-22 for ITB2); an extracellular integrin beta region (pfam00362) (residues 32-447) including a potential cell attachment site (residues 397-399) and a region of cysteine-rich tandem repeats (residues 414-617); an integrin beta tail domain (pfam07965) (residues 622-700); a transmembrane helical region (residues 701-723) (see Figure 1 for ITB2 TMHMM region), which anchors ITB2 to the cell membrane; and an ITB2 cytoplasmic region (residues 724-768). 
Table 1. Vertebrate beta integrin and nematode beta integrin-like genes and proteins. RefSeq: the reference amino acid sequence; ${ }^{1,3}$ predicted Ensembl amino acid sequence; ${ }^{2}$ not available; ${ }^{4}$ Contig refers to a DNA scaffold for sequencing analyses; GenBank IDs are derived NCBI http://www.ncbi.nlm.nih.gov/genbank/; Ensembl ID was derived from Ensembl genome database http://www.ensembl.org/; UNIPROT refers to UniprotKB/Swiss-Prot IDs for individual acid lipases (see http://kr.expasy.org/); bps refers to base pairs of nucleotide sequences; pI refers to theoretical isoelectric points; the number of coding exons are listed.

\begin{tabular}{|c|c|c|c|c|c|c|c|c|c|c|}
\hline Animal & Species & $\begin{array}{l}\text { Integrin } \\
\text { Beta Gene } \\
\text { (subunit) }\end{array}$ & $\begin{array}{l}\text { Other } \\
\text { Gene } \\
\text { Name } \\
\end{array}$ & $\begin{array}{l}\text { Chromosome } \\
\text { Coordinates }\end{array}$ & \begin{tabular}{|l|} 
Gene \\
Size \\
$($ kbps $)$ \\
\end{tabular} & $\begin{array}{l}\text { Coding } \\
\text { Exons } \\
\text { (Strand) } \\
\end{array}$ & $\begin{array}{l}\text { Subunit } \\
\text { MW }\end{array}$ & $\begin{array}{l}\text { Amino } \\
\text { Acids }\end{array}$ & $\begin{array}{l}\mathrm{NCBI}^{1,2} \\
\text { ID }\end{array}$ & $\begin{array}{l}\text { UNIPROT }^{2} \\
\text { ID }\end{array}$ \\
\hline Human & Homo sapiens & $\operatorname{ITB1}(\beta 1)$ & ITGBI & $10: 33,190,501-33,224,486$ & 35.2 & $16(-)$ & 88,415 & 798 & NM_002211 & P05556 \\
\hline Mouse & Mus musculus & $I t b 1(\beta 1)$ & Itgbl & $8: 131,209,552-131,257,438$ & 47.9 & $15(+)$ & 88,231 & 798 & NM_010578 & P09055 \\
\hline Horse & Equus caballus & $\operatorname{ITB1}(\beta 1)$ & $I T G B 1$ & 29:5,050,336-5,076,608 & 26.3 & $15(+)$ & 88,202 & 798 & XP_001492715 & na \\
\hline Opossum & Monodelphis domestica & $\operatorname{ITB1}(\beta 1)$ & $I T G B 1$ & $8: 240,074,436-240,104,533$ & 30.1 & $15(+)$ & 88,329 & 799 & XP_001366567 & na \\
\hline Chicken & Gallus gallus & ITB1 $(\beta 1)$ & $I T G B 1$ & $2: 13,977,440-14,000,322$ & 22.9 & $15(+)$ & 88,554 & 803 & NP_001034343 & P07228 \\
\hline Frog & Xenopus tropicalis & $\operatorname{ITB} 1(\beta 1)$ & $I T G B 1$ & $503^{5}: 452,582-465,188$ & 12.6 & $15(+)$ & 88,083 & 798 & NP_989160 & Q6P4X1 \\
\hline Zebrafish & Danio rerio & $\operatorname{ITB1A}(\beta 1 A)$ & $I T G B 1 A$ & $24: 1,010,009-1,028,526$ & 18.5 & $15(-)$ & 88,592 & 798 & NP_001030143 & Q3YAA1 \\
\hline Zebrafish & Danio rerio & $\operatorname{ITB} 1 B(\beta 1 B)$ & $I T G B 1 B$ & $2: 42,692,236-42,708,345$ & 16.1 & $15(+)$ & 86,570 & 787 & NP_001030151 & Q3YA99 \\
\hline Human & Homo sapiens & ITB2 $(\beta 2)$ & ITGB2 & $21: 46,306,286-46,330,697$ & 40.0 & $15(-)$ & 84,782 & 769 & NM_001127491 & P05107 \\
\hline Mouse & Mus musculus & $I t b 2(\beta 2)$ & Itgb2 & $10: 76,993,093-77,028,419$ & 35.3 & $15(+)$ & 85,026 & 771 & NM_008404 & P11835 \\
\hline Mouse & Mus musculus & $I t b 2 l(\beta 2 l)$ & Itgb2l & $16: 96,643,905-96,665,221$ & 21.3 & $15(-)$ & 81,547 & 738 & NM_008405 & Q3UV74 \\
\hline Horse & Equus caballus & $I T B 2 A(\beta 2 A)$ & $I T G B 2 A$ & $26: 39,992,918-40,009,865$ & 16.9 & $15(-)$ & 85,290 & 770 & XP_001490052 $2^{2}$ & na \\
\hline Horse & Equus caballus & $I T B 2 B(\beta 2 B)$ & $I T G B 2 B$ & $26: 40,054,164-40,069,857$ & 15.7 & $14(-)$ & 79,824 & 726 & $\operatorname{chr} 26.199 .1^{3}$ & na \\
\hline Opossum & Monodelphis domestica & $\operatorname{ITB2}(\beta 2)$ & ITGB2 & $2: 539,079,162-539,090,540$ & 11.4 & $13(-)$ & 83,015 & 761 & chr2.11.580. $\mathrm{a}^{3}$ & na \\
\hline Chicken & Gallus gallus & $\operatorname{ITB2}(\beta 2)$ & $I T G B 2$ & $7: 7,143,899-7,150,094$ & 6.2 & $15(-)$ & 85,409 & 772 & NP_990582 & na \\
\hline Frog & Xenopus tropicalis & $\operatorname{ITB} 2(\beta 2)$ & $I T G B 2$ & $2185: 1,356,257-1,405,734$ & 49.5 & $16(-)$ & 86,980 & 782 & XP_002936570 ${ }^{2}$ & na \\
\hline Zebrafish & Danio rerio & ITB2 $(\beta 2)$ & $I T G B 2$ & $9: 47,603,423-47,619,406$ & 16.0 & $15(+)$ & 84519 & 768 & XP_686012 $2^{2}$ & na \\
\hline Human & Homo sapiens & ITB3 $(\beta 3)$ & ITGB3 & $17: 45,331,228-45,387,567$ & 37.4 & $9(+)$ & 87,058 & 788 & NM_000212 & P05106 \\
\hline Mouse & Mus musculus & Itb3 $(\beta 3)$ & $\operatorname{Itg} b 3$ & $11: 104,469,370-104,528,689$ & 59.3 & $15(+)$ & 86,694 & 787 & NM_016780 & O54890 \\
\hline
\end{tabular}


Table 1. Cont.

\begin{tabular}{|c|c|c|c|c|c|c|c|c|c|c|}
\hline Animal & Species & $\begin{array}{l}\text { Integrin } \\
\text { Beta Gene } \\
\text { (subunit) }\end{array}$ & $\begin{array}{l}\text { Other } \\
\text { Gene } \\
\text { Name }\end{array}$ & $\begin{array}{l}\text { Chromosome } \\
\text { Coordinates }\end{array}$ & $\begin{array}{l}\text { Gene } \\
\text { Size } \\
(\text { kbps }) \\
\end{array}$ & $\begin{array}{l}\text { Coding } \\
\text { Exons } \\
\text { (Strand) }\end{array}$ & $\begin{array}{l}\text { Subunit } \\
\text { MW }\end{array}$ & $\begin{array}{l}\text { Amino } \\
\text { Acids }\end{array}$ & $\begin{array}{l}\text { NCBI }{ }^{1,2} \\
\text { ID }\end{array}$ & $\begin{array}{l}\text { UNIPROT }^{2} \\
\text { ID }\end{array}$ \\
\hline Horse & Equus caballus & $\operatorname{ITB} 3(\beta 3)$ & ITGB3 & $11: 17,206,504-17,237,153$ & 30.7 & $15(-)$ & 86,360 & 784 & NM_001081802 & na \\
\hline Opossum & Monodelphis domestica & $\operatorname{ITB} 3(\beta 3)$ & ITGB3 & $2: 208,102,619-208,154,477$ & 51.9 & $14(+)$ & 84,497 & 764 & $\operatorname{chr} 2.5 .154 . \mathrm{a}^{3}$ & na \\
\hline Chicken & Gallus gallus & $\operatorname{ITB} 3(\beta 3)$ & $I T G B 3$ & $27: 2,207,723-2,223,943$ & 16.2 & $15(+)$ & 86,088 & 781 & NP_989646 & na \\
\hline Frog & Xenopus tropicalis & $\operatorname{ITB} 3(\beta 3)$ & ITGB3 & $973^{5}: 169,881-200,256$ & 30.4 & $15(-)$ & 88,235 & 792 & XP_002942401 ${ }^{3}$ & na \\
\hline Zebrafish & Danio rerio & $\operatorname{ITB} 3 \mathrm{~A}(\mathrm{B3 \textrm {A }})$ & ITGB3A & $3: 16,152,931-16,181,252$ & 28.3 & $15(+)$ & 85,693 & 785 & NP_001032312 & Q3LTM4 \\
\hline Zebrafish & Danio rerio & $\operatorname{ITB} 3 B(\beta 3 \mathrm{~B})$ & $I T G B 3 B$ & $12: 21,495,417-21,520,656$ & 25.2 & $15(-)$ & 87,700 & 790 & NP_001076417 & B3DIP9 \\
\hline Human & Homo sapiens & ITB4 ( $\beta 4)$ & $I T G B 4$ & $17: 73,720,784-73,753,633$ & 36.4 & $39(+)$ & 202,167 & 1,822 & NM_000213 & P16144 \\
\hline Mouse & Mus musculus & Itb4 ( $\beta 4)$ & $\operatorname{Itg} 44$ & $11: 115,836,039-115,869,725$ & 33.7 & $39(+)$ & 201,650 & 1,818 & NM_133663 & A2A863 \\
\hline Horse & Equus caballus & ITB4 ( $\beta 4)$ & $I T G B 4$ & $11: 6,286,192-6,312,590$ & 26.4 & $39(-)$ & 194,864 & 1,752 & XP_001915915² & na \\
\hline Opossum & Monodelphis domestica & ITB4 ( $\beta 4)$ & $I T G B 4$ & $2: 213,276,209-213,319,767$ & 43.6 & $36(-)$ & 198,824 & 1,778 & XP_001377606 ${ }^{2}$ & na \\
\hline Chicken & Gallus gallus & ITB4 ( $\beta 4)$ & $I T G B 4$ & $18: 4,713,504-4,732,758$ & 19.3 & $39(-)$ & 203,330 & 1,818 & $\mathrm{E} 1 \mathrm{C} 9 \mathrm{G} 7^{4}$ & E1C9G7 \\
\hline Frog & Xenopus tropicalis & ITB4 ( $\beta 4)$ & $I T G B 4$ & $545^{5}: 495,511-545,134$ & 49.6 & $38(+)$ & 204,208 & 1,835 & XP_002940020 & na \\
\hline Zebrafish & Danio rerio & ITB4 ( $\beta 4)$ & ITGB4 & $8: 13,034,599-13,080,896$ & 46.3 & $39(+)$ & 210,736 & 1,893 & NP_001019557 & Q4U0S1 \\
\hline Human & Homo sapiens & ITB5 ( $\beta 5)$ & ITGB5 & $3: 124,482,473-124,605,847$ & 139.5 & $15(-)$ & 88,054 & 799 & $\mathrm{BC}^{2} 006541^{6}$ & $\mathrm{P} 18084$ \\
\hline Mouse & Mus musculus & $\operatorname{Itb5}(\beta 5)$ & $\operatorname{Itg} 55$ & $3: 126,102,954-125,963,482$ & 139.5 & $15(+)$ & 87,909 & 798 & NM_010580 & O70309 \\
\hline Horse & Equus caballus & ITB5 ( $\beta 5)$ & ITGB5 & $19: 34,769,099-34,876,312$ & 107.2 & $15(+)$ & 87,985 & 803 & XP_001500077 ${ }^{2}$ & na \\
\hline Opossum & Monodelphis domestica & ITB5 ( $\beta 5)$ & ITGB5 & 4:90,575,064-90,751,974 & 17.7 & $14(-)$ & 86,072 & 779 & XP_001372711 ${ }^{2}$ & na \\
\hline Chicken & Gallus gallus & ITB5 $(\beta 5)$ & ITGB5 & $7: 29,463,064-29,500,494$ & 37.4 & $15(-)$ & 88,475 & 812 & NP_989814 & na \\
\hline Frog & Xenopus tropicalis & ITB5 $(\beta 5)$ & ITGB5 & 6 & 6 & 6 & 87,561 & 807 & NP_001135704 & B5DEV6 \\
\hline Zebrafish & Danio rerio & ITB5 $(\beta 5)$ & ITGB5 & $9: 22,031,538-22,101,156$ & 69.6 & $16(+)$ & 88,956 & 802 & NP_001076305 & A5D6V1 \\
\hline Human & Homo sapiens & ITB6 $(\beta 6)$ & $I T G B 6$ & $2: 160,958,250-161,056,574$ & 172.2 & $15(-)$ & 85,936 & 788 & NM_000888 & P18564 \\
\hline
\end{tabular}


Table 1. Cont

\begin{tabular}{|c|c|c|c|c|c|c|c|c|c|c|}
\hline Animal & Species & $\begin{array}{l}\text { Integrin } \\
\text { Beta Gene } \\
\text { (subunit) }\end{array}$ & $\begin{array}{l}\text { Other } \\
\text { Gene } \\
\text { Name }\end{array}$ & $\begin{array}{l}\text { Chromosome } \\
\text { Coordinates }\end{array}$ & $\begin{array}{l}\text { Gene } \\
\text { Size } \\
(\text { kbps }) \\
\end{array}$ & $\begin{array}{l}\text { Coding } \\
\text { Exons } \\
\text { (Strand) }\end{array}$ & $\begin{array}{l}\text { Subunit } \\
\text { MW }\end{array}$ & $\begin{array}{l}\text { Amino } \\
\text { Acids }\end{array}$ & $\begin{array}{l}\text { NCBI }{ }^{1,2} \\
\text { ID }\end{array}$ & $\begin{array}{l}\text { UNIPROT }^{2} \\
\text { ID }\end{array}$ \\
\hline Mouse & Mus musculus & $\operatorname{Itb6}(\beta 6)$ & Itgb6 & $2: 160,836,644-160,664,416$ & 172.2 & $15(+)$ & 86,042 & 787 & NM_021359 & Q9Z0T9 \\
\hline Horse & Equus caballus & $\operatorname{ITB6}(\beta 6)$ & ITGB6 & $18: 40,790,052-40,860,613$ & 70.6 & $15(-)$ & 85,817 & 788 & XP_001492914 ${ }^{2}$ & na \\
\hline Opossum & Monodelphis domestica & $\operatorname{ITB6}(\beta 6)$ & ITGB6 & $4: 165,626,656-165,720,419$ & 93.8 & $15(-)$ & 86,274 & 787 & ENSMODT6582 $^{3}$ & na \\
\hline Chicken & Gallus gallus & $\operatorname{ITB6}(\beta 6)$ & ITGB6 & $7: 23,382,214-23,409,883$ & 27.7 & $15(+)$ & 86,530 & 789 & XP_422037² & E1C6K8 \\
\hline Frog & Xenopus tropicalis & $\operatorname{ITB6}(\beta 6)$ & ITGB6 & $51^{5}: 1,605,719-1,638,193$ & 32.5 & $13(+)$ & 76,152 & 696 & NP_001090775 & A4IGI8 \\
\hline Human & Homo sapiens & $\operatorname{ITB7}(\beta 7)$ & $I T G B 7$ & $12: 53,585,343-53,594,227$ & 16.3 & $15(-)$ & 86,903 & 798 & NM_000889 & P26010 \\
\hline Mouse & Mus musculus & $I t b 7(\beta 7)$ & $\operatorname{Itg} b 7$ & $15: 102,046,428-102,062,317$ & 15.9 & $15(-)$ & 87,411 & 806 & NM_013566 & P26011 \\
\hline Horse & Equus caballus & $\operatorname{ITB7}(\beta 7)$ & ITGB7 & $6: 70,193,060-70,201,400$ & 8.3 & $14(-)$ & 86,666 & 797 & XP_001494917 ${ }^{2}$ & na \\
\hline Frog & Xenopus tropicalis & $\operatorname{ITB7}(\beta 7)$ & ITGB7 & $226: 1,387,775-1,412,224$ & 24.5 & $15(+)$ & 84,461 & 766 & XP_002936686 ${ }^{2}$ & na \\
\hline Zebrafish & Danio rerio & $\operatorname{ITB7}(\beta 7)$ & ITGB7 & $6: 43,251,691-43,271,173$ & 19.5 & $15(-)$ & 74,006 & 661 & XP_001337949 ${ }^{2}$ & na \\
\hline Human & Homo sapiens & $\operatorname{ITB} 8(\beta 8)$ & $I T G B 8$ & 7:20,371,430-20,449,617 & 85.1 & $14(+)$ & 85,632 & 769 & NM_002214 & P26012 \\
\hline Mouse & Mus musculus & $\operatorname{Itb8}(\beta 8)$ & $\operatorname{Itg} 88$ & $12: 120,477,276-120,396,490$ & 80.8 & $14(-)$ & 84,519 & 767 & NM_177290 & Q0VDB0 \\
\hline Horse & Equus caballus & $\operatorname{ITB} 8(\beta 8)$ & ITGB 8 & 4:52,216,892-52,290,256 & 73.4 & $14(+)$ & 85,361 & 767 & XP_001497271 ${ }^{2}$ & na \\
\hline Opossum & Monodelphis domestica & $\operatorname{ITB} 8(\beta 8)$ & $I T G B 8$ & $8: 302,826,175-302,899,169$ & 73.0 & $14(-)$ & 83,721 & 757 & XP_001371834 ${ }^{2}$ & na \\
\hline Chicken & Gallus gallus & $\operatorname{ITB} 8(\beta 8)$ & $I T G B 8$ & 2:30,002,182-30,052,908 & 49.3 & $15(+)$ & 86,990 & 786 & XP_418706 ${ }^{2}$ & na \\
\hline Frog & Xenopus tropicalis & $\operatorname{ITB} 8(\beta 8)$ & ITGB8 & $52^{5}: 945,865-97,887$ & 33.0 & $14(-)$ & 81,104 & 728 & XP_002933344 ${ }^{2}$ & na \\
\hline Zebrafish & Danio rerio & $\operatorname{ITB} 8(\beta 8)$ & $I T G B 8$ & $19: 2,377,677-2,441,753$ & 64.1 & $14(-)$ & 74,877 & 669 & XP_001919626 ${ }^{2}$ & A3RI57 \\
\hline Nematode & Caenorhabditis elegans & PAT3 & pat3 & III:3,909,309-3,914,106 & 4.8 & $8(-)$ & 90,138 & 809 & NP_497787 & Q27874 \\
\hline
\end{tabular}


Figure 1. Predicted domains and transmembrane helix for human ITB2 and ITB4. Domains and key regions are identified for ITB2 and ITB4 amino acid sequences using NCBI web tools (http://www.ncbi.nlm.nih.gov/Structure/cdd/wrpsb.cgi) to identify functional domains and ExPasy web tools to identify predicted transmembrane domains (TMHMM) (http://www.cbs.dtu.dk/services/TMHMM-2.0/); INB or integrin_beta; integrin B tail (in pink); TMHMM transmembranes (in red); cytosolic domain (in blue); Calx-beta domain (in green); FN3 (fibronectin 3), cytokine receptor and interdomain contacts (red triangles); Note: lack of FN3 binding domains and the cytokine receptor motifs in $\beta 4$ subunit that interacts only with laminin-332.

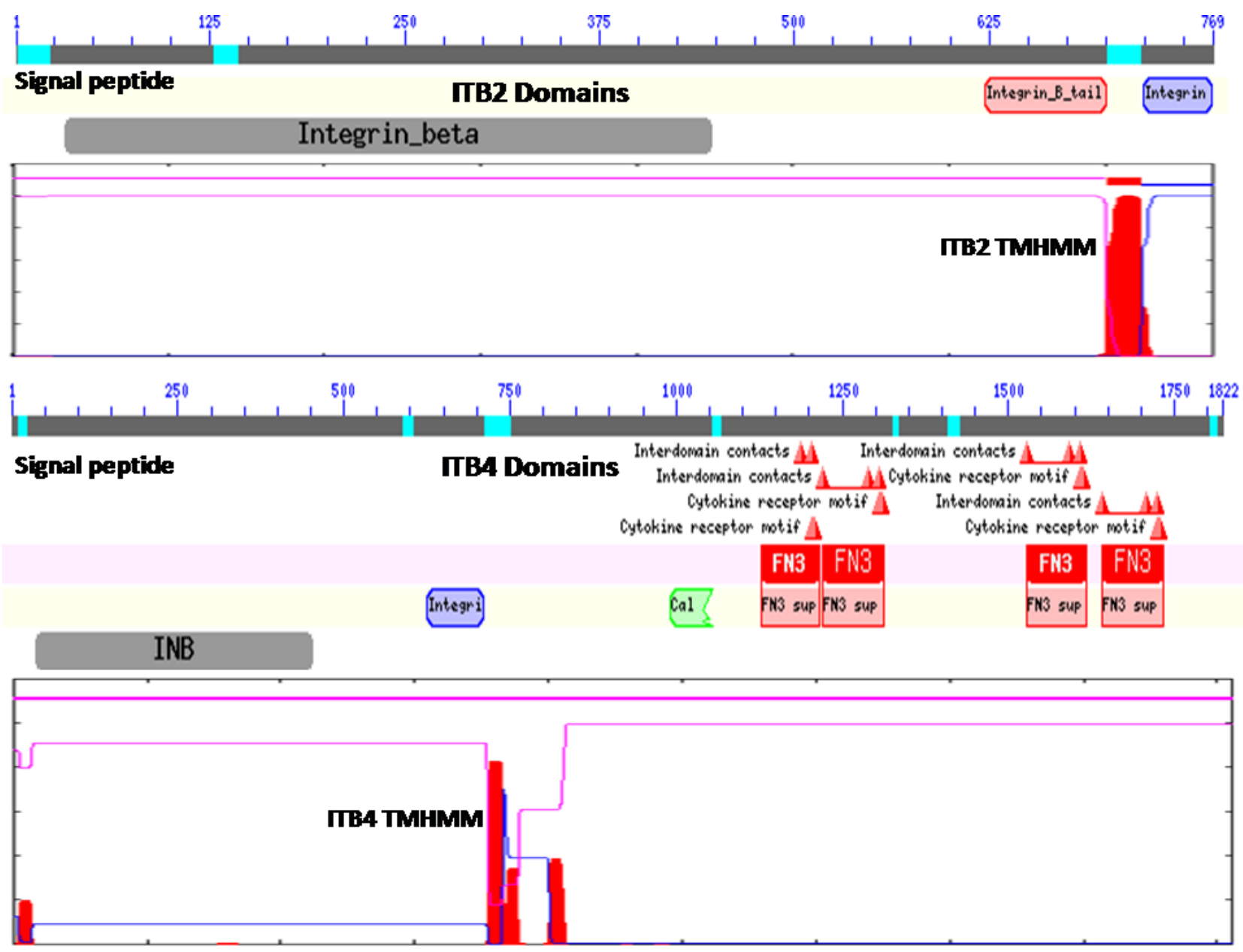

In contrast, ITB4 is a much larger protein compared with the other beta-integrins (1822 residues compared with 769-798 residues) and contains several beta-integrin-like domains in the $N$-terminal half of the protein [12,53,54] including the $N$-signal peptide (residues 1-27); an $N$-terminal extracellular beta-integrin domain (residues 37-453); a cysteine-rich tandem-repeat region (residues 456-619); an integrin beta-tail region (residues 626-711); and an ITB4 transmembrane-helix anchor region (residues 711-733) (Figure 1). The cytoplasmic region of ITB4 contains four fibronectin type III (FN3) domains (residues 1128-1215; 1220-1313; 1528-1628; and 1641-1734) and a Calx-beta motif (residues 991-1054) which are responsible for most of the intracellular interactions of the integrin [53-56]. Other key cytoplasmic ITB4 domains include several interdomain contact sites (residues 1641, 1708 and 1723) and cytokine-receptor motifs (1608-1609 and 1611-1612). 


\subsection{Alignments of Vertebrate ITB Cytosolic Isoform Sequences}

The cytoplasmic domains of $\beta$ subunits interact with several intracellular proteins. Many of these interactions are known to cause conformational change in the extracellular domain changing the affinity of the receptor with the ECM. The interactions of extracellular domains with the ECM may also cause change in the conformation of the cytosolic domain allowing its interaction with the non-receptor tyrosine kinases and the actin cytoskeleton. Therefore, the cytoplasmic domain of integrin $\beta$ subunits plays crucial roles in both 'outside-in' and 'inside-out'signaling [12-14]. Figure 2 examines alignments of vertebrate ITB1 cytosolic domain sequences which are color coded for amino acid residue properties. With the exception of a second duplicated ITB1.1 (designated as ITB1B) gene product observed in zebrafish (Danio rerio), identical sequences were observed for the ITB1 cytosolic domain for all vertebrates examined, which indicates that this is a highly conserved region of ITB1 which undertakes essential functions and is subject to selection and maintenance of this sequence. Comparisons of the cytosolic domain sequences for the other ITB proteins (alignments not shown) revealed lower levels of amino acid sequence identities as compared with the highly conserved ITB1 cytosolic domain sequence: ITB2 (37\% identities); ITB3 (77\% excluding the gene duplicate product ITB3B from zebrafish); ITB5 (50\%); ITB6 (74\%); ITB7 (35\%); and ITB8 (45\%).

Figure 2. Amino acid alignments for vertebrate ITB1 cytosolic domain sequences. ITB1 sequences examined included Hu-human; Rh-rhesus; Ma-marmoset; Mo-mouse; Ra-rat; Gp-guinea pig; Ho-horse; Co-cow; Pi-pig; Op-opossum; Ch-chicken; Fr-Xenopus tropicalis; Zf-zebrafish; see Table 1 for details; note that 2 ITB1-like genes were observed in zebrafish (designated as ITB1A and ITB1B); * shows identical residues for ITB subunits; : similar alternate residues; . dissimilar alternate residues; $\alpha$-helix for vertebrate ITB sequences is in shaded yellow; $\beta$-sheet is in shaded grey; colors for amino acids are shown as: basic ( $R$ and $\mathrm{K}$ ); acidic (D and $\mathrm{E}$ ); neutral hydrophilic $(\mathrm{G}, \mathrm{Y}, \mathrm{Q}, \mathrm{S}, \mathrm{T}, \mathrm{N}, \mathrm{Y}, \mathrm{C}$, H); and hydrophobic (M, A, F, I, L, W, P, V); the Cyto-1, Cyto-2 (NPXY) and Cyto-3 (NXXY) domains are shown in dotted lines (see text for details).

\begin{tabular}{|c|c|}
\hline HaITB1 & 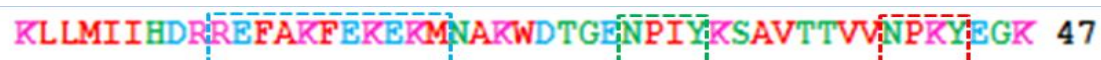 \\
\hline RhITB1 & 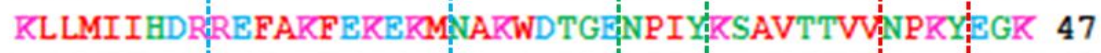 \\
\hline MaITB1 & REFARFERERMNAKWDTGEANPIY'KSAVTTVVNAPKYGK \\
\hline MoITB1 & 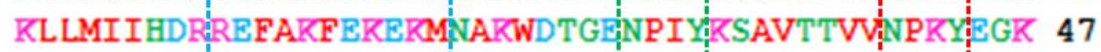 \\
\hline RaITB1 & 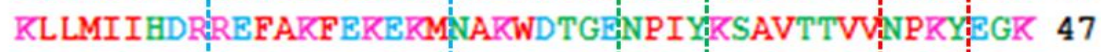 \\
\hline GpITB1 & KLLMIIHDRREFARFEKERMMARWD \\
\hline HoITB1 & TTVVINARYEGK 47 \\
\hline CoITB1 & IYKSAVTTVVANPRYGGK 47 \\
\hline PiITB1 & KLLMI I HDRREFAKFEKERMNAKWDTGH \\
\hline OpITB1 & KLLMI I HDR REFAKFEKERMNAKWDTGE \\
\hline ChITB1 & 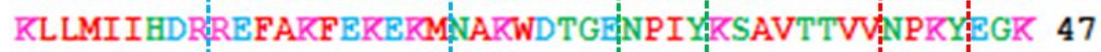 \\
\hline FrITB1 & KLLMIIHDREFARF ERERMNA_KWDTGG \\
\hline ZfITB1A & 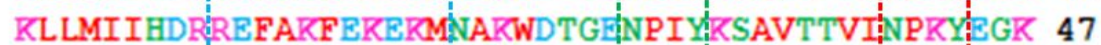 \\
\hline $\mathrm{ZfITB} 1 \mathrm{~B}$ & 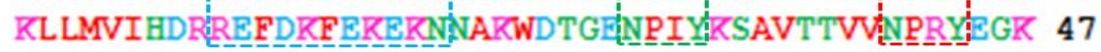 \\
\hline
\end{tabular}


Figure 3A shows amino acid sequence alignments for the six major human ITB1 isoforms designated as ITB1a-ITB1f [57]. Residues 1-26 were identical for each of the isoforms which contained the 19 residue $\alpha$-helix region, whereas the $C$-terminal differed in length and sequence and exhibited 1-2 predicted $\beta$-sheet regions. Recent studies [58] have shown that ITB1a is expressed in fetal muscles but is substituted by ITB1d during postnatal development. The $C$-terminal region is exposed at the cytoplasmic face of the plasma membrane where it is bound to the actin filaments. ITB1d is expressed only in striated muscle tissues and binds to both cytoskeletal and extracellular matrix proteins with an affinity higher than ITB1a which provides a stronger link between the cytoskeleton and extracellular matrix to support mechanical tension during muscle contraction. ITA1a and ITA1b have been shown to be similar as far as the alpha/beta association and fibronectin binding are concerned but differ, however, in their subcellular localization. ITB1a has been localized in focal adhesions whereas ITBb does not and exhibits distinct properties [22]. Human ITB1 isoforms are differentially expressed in tissues and exhibit distinct binding properties. HumanITB1a is widely expressed and usually coexpressed with other isoforms with a more restricted distribution. ITB $1 \mathrm{~b}$ is expressed in skin, liver, skeletal muscle, cardiac muscle, placenta, umbilical vein endothelial cells, neuroblastoma cells, lymphoma cells, hepatoma cells and astrocytoma cells. ITB1c is expressed in muscle, kidney, liver, placenta, cervical epithelium, umbilical vein endothelial cells, fibroblast cells, embryonic kidney cells, platelets and several blood cell lines, whereas ITB1d is expressed specifically in striated muscle (skeletal and cardiac muscle).

Figure 3. Amino acid sequence alignments for vertebrate ITB cytosolic domain sequences. (A) Comparison and alignments of human ITB1 major isoforms for cytosolic domain sequences; (B) Consensus sequences of vertebrate ITB cytosolic domains; see Table 1 for sources of beta integrin cytosolic domain sequences: * shows identical residues for ITB subunits; : similar alternate residues; . dissimilar alternate residues; $\alpha$-helix for vertebrate ITB sequences is in shaded yellow; $\beta$-sheet is in shaded grey; colors for amino acids are shown as: basic ( $R$ and $\mathrm{K}$ ); acidic (D and $\mathrm{E}$ ); neutral hydrophilic ( $\mathrm{G}, \mathrm{Y}, \mathrm{Q}, \mathrm{S}, \mathrm{T}, \mathrm{N}, \mathrm{Y}, \mathrm{C}$, H); and hydrophobic (M, A, F, I, L, W, P, V); the Cyto-1, Cyto-2 (NPXY) and Cyto-3 (NXXY) domains are shown in dotted lines (see text for details).

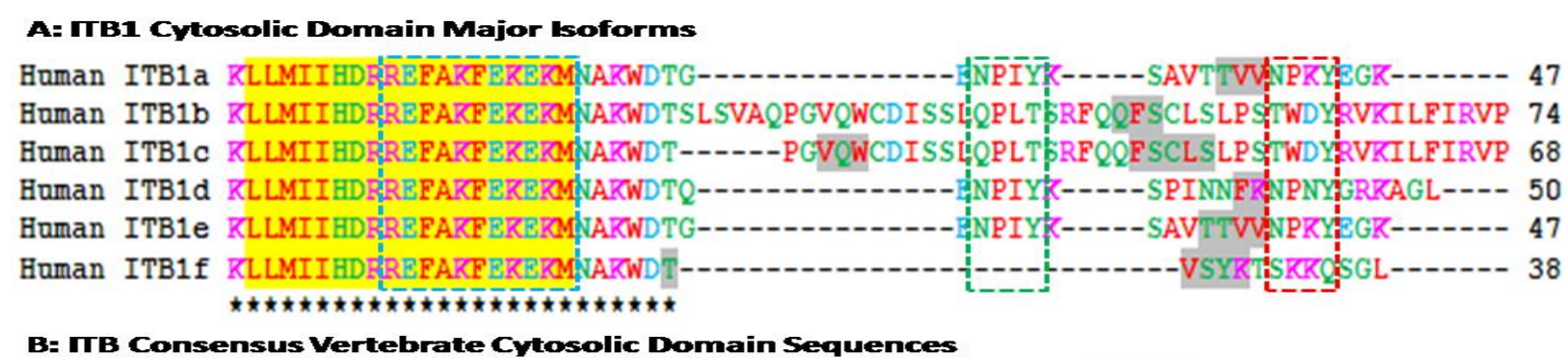

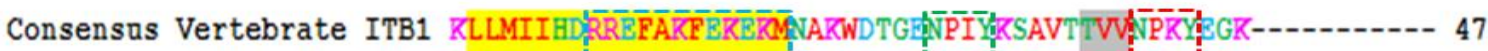

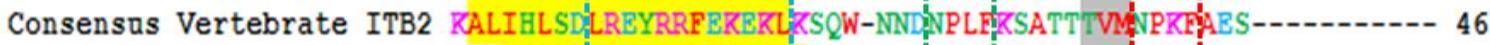

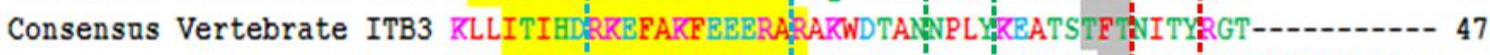
Consensus Vertebrate ITB5 RLLVTIHDRREFAKFQSERSRARYEMASINPLYRKPISTHIVDFTENKFNRSYNGTVD- 57 Consensus Vertebrate ITB6 RLLVSFHDRREVAKFBABRSKARWQTGTINPLYRGSTSTFANVTYKHRBRQRVDLSTDC 58 Consensus Vertebrate ITB7 RLSVEIYDRREYSRFBREQDLNWKQDSNPLYKSAITTTIFNRRFREADSPTL------ 52 $:: \star_{.}::^{\star} \star \quad: \quad \star \star \star:: \quad: \star$. 
Amino acid sequence alignments for vertebrate consensus sequences ITB cytosolic domains are shown in Figure 3B. Human ITB sequences were based on previous reports for ITB1 [21-24]; ITB2 [25-27]; ITB3 [28-31]; ITB5 [35-37]; ITB6 [38,40]; ITB7 [39,41-42]; and ITB8 [43-44]. With the exception of the human ITB8 sequence, the other ITB sequences were of similar length (46-58 amino acids) and shared a predicted 19 residue $\alpha$-helix region (residues 2-20 for human ITB1) whereas the human ITB 8 sequence contained 65 amino acids with 6 predicted $\beta$-sheets.

The cytoplasmic tail of the ITB4 subunit is exceptionally long (1072 residues) compared to other ITB subunits [33] that are much shorter (Figure 3). Point mutation analysis of the cytoplasmic sequences of these $\beta$ integrin subunits reveal three clusters of amino acids in the $\beta$ cytoplasmic tail that regulate the interaction of integrins with the cytoskeleton, localization of receptors at the adhesion complex and inside-out signaling [12-13,59-62]. These three clusters of amino acids (Signalins) are commonly known as cyto 1, cyto-2 and cyto-3: cyto-1 is present in the vicinity of transmembrane domain, whereas cyto-2 (NPXY motif) and cyto-3 (NXXY motif) are located in the proximal and distal regions respectively of a tail (Figure 2) [63]. Alignment results of ITB1 subunits of different species (Figure 2) and spliced versions of ITB1subunits (Figure 3A) show that the cyto-1 residues remain highly conserved indicating their conservation during vertebrate evolution for their specificity in function. Recent studies have shown that the interaction between the conserved arginine residue in the $\alpha$-tail and aspartate residue in the $\beta$-tail, and by the hydrophobic residues immediately $N$-terminal to the arginine and aspartate residues play important role in 'inside-out' signalling by forming a 'clasp' between the $\alpha$ and $\beta$ subunits [64-65].

The cyto-3 sequence in contrary varied amongst the spliced versions of ITB 1 and the different ITB subunits (Figure 3). Therefore, the variability in the functions of different spliced versions of ITB1 (Figure 3A) and amongst different ITB isoforms (Figure 3B) may be derived from the differences in the cyto 2 and cyto 3 sequences. Moreover, each $\beta$ subunit conceals distinct differences in its affinity towards intracellular proteins that is shown to be dictated by the ' $X$ ' and the neighboring amino acids of these motifs [66]. For instance, the binding of ICAP-1 $\alpha$, a 200amino acid protein, with the cyto-3 is influenced by the proximal Val787 and Val 790 [66-68]. The NPXY and NXXY motifs, with the propensity to form $\beta$ turns, act as canonical recognition sequences of intracellular proteins with phosphotyrosine-binding domains (PTB) [66]. These include the interaction of $\beta 1 \mathrm{~A}$ tail with the PTB domain of talin, EPS8 and Dab1; $\beta 2$ tail with Dok-1 and talin; $\beta 3$ tail with Numb, Dab1, EPS8, Tensin, Dok-1 and talin; $\beta 5$ tail with Numb, Dab1, Dab2, EPS8, Tensin, Dok-1 and talin and the $\beta 7$ tail with tensin, Dok-1 and Talin [67].

Recent studies have reported that cytosolic proteins kindlin-1, 2 and 3 are essential for integrin activation [68-69]. Immuno-precipitation assays with $\beta$ integrin tails show that isoforms of kindlins bind with membrane proximal NPXY and membrane distal NXXY motifs as well as neighboring residues (NPXY linker region) of the $\beta$ integrin subunit [69]. Several other cytosolic proteins (including filamin, melusin and myosin) also bind both conserved and non-conserved domains of $\beta$ cytoplasmic tails [70]. Therefore, differences in the residues within and around these motifs in vertebrate $\beta$ integrin subunits may change the affinities of these cytosolic proteins with the $\beta$ integrin tail. Phosphorylation of the tyrosine residue in the distal NXXY motif of the $\beta 3$ subunit disrupts the recognition by kindlin-2 and co-activation of aIIb.b3 integrin by talin [71-72]. The phosphoryalated or unphosphorylated state of tyrosines may also determine the affinities of proteins with the cytosolic tail. 
The unphosphorylated state of Y747 in the of $\beta 3$ integrin tail has a 3 fold preference for the talin over the PTB domain of Dok1, whereas with the phosphorylated state of Y747, this affinity is increased 400 fold for Dok1 and decreased 2 fold for talin [73]. A recent study shows that phosphorylation of tyrosine 759 inhibits binding of kindling-2 with the $C$-terminal $\beta 3$ chain [71]. Thus the expression patterns of different $\beta$ subunits (Figure 5) and interacting proteins in the cytosol as well the phosphorylation state of ' $\mathrm{Y}$ ' may determine the functional output of the integrin receptors.

\subsection{Human ITB genes: Introns, Isoforms and Predicted Regulatory Regions}

Figure 4 shows the predicted structures of mRNAs for human ITB transcripts for the major isoform in each case [57]. The transcripts were 3.0-9.2 kbs in length and exhibited distinct exonic structures in each case, including extended 3'-untranslated regions (UTR), especially for ITB3a, ITB6a and ITB8a transcripts. The number of ITB introns varied widely among the vertebrate genes examined: the ITB4 gene contained the largest number of introns (39) followed by ITB1 (16), ITB2 and ITB7 (15), ITB3, ITB5 and ITB6 (14) and ITB8 (13).

Figure 4. Structures and major splicing isoforms for human beta integrin genes. Derived from the AceView website http://www.ncbi.nlm.nih.gov/IEB/Research/Acembly/ [57]; mature isoform variants (a) are shown with capped 5'- and 3'- ends for the predicted mRNA sequences; NM refers to the NCBI reference sequence; exons are in pink; the directions for transcription are shown as $5^{\prime} \rightarrow 3^{\prime}$; sizes of mRNA sequences are shown in kilobases $(\mathrm{kb})$.

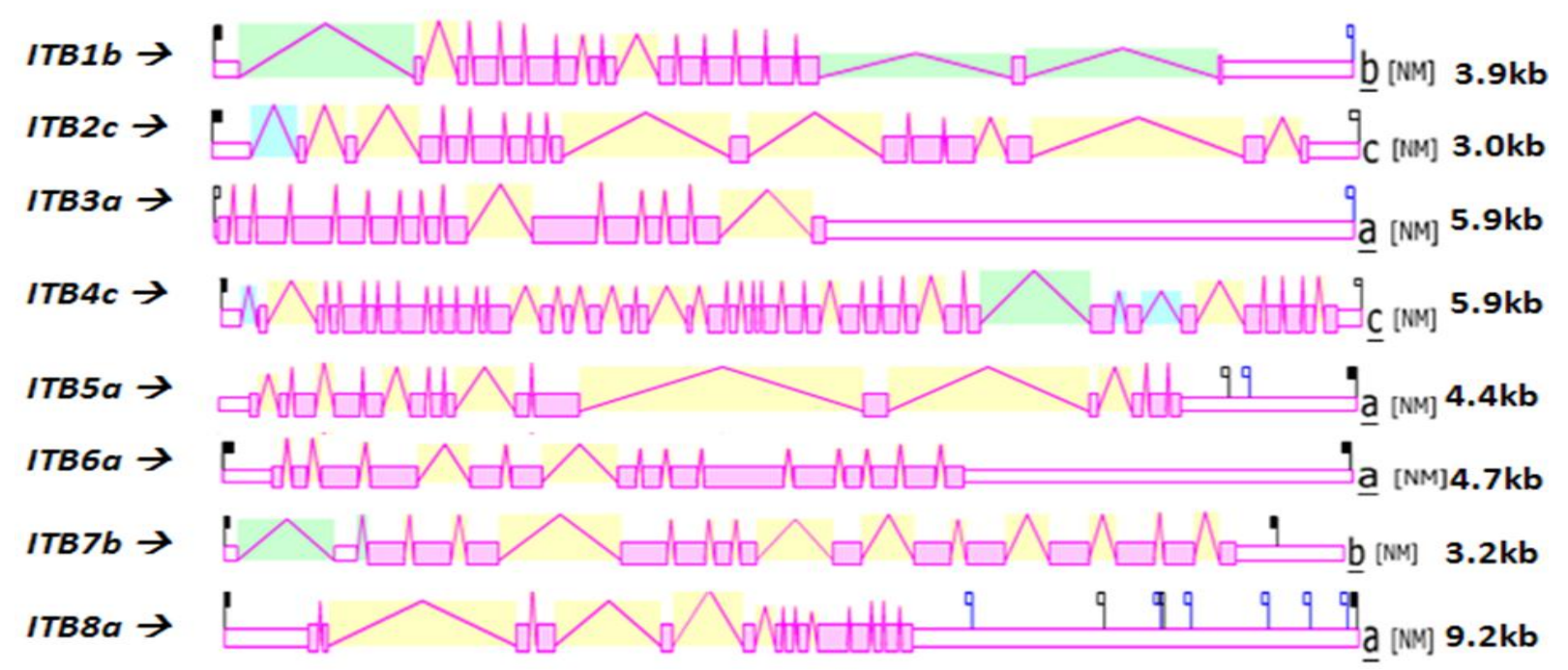

The human ITB genome sequences contained several predicted transcription factor binding sites (TFBS), microRNA sites located in the 3'-untranslated region and $\mathrm{CpG}$ islands, which included CpG158, CpG92, CpG91, CpG152 and CpG133 located in the 5'-untranslated region of human ITB1, ITB3, ITB4, ITB5 and ITB8, respectively (see Table 2). These $\mathrm{CpG}$ islands within the ITB gene promoters may play major contributing roles in maintaining high levels of gene expression (1.4-6.1 times the average for human genes) [57] which are similar to $\mathrm{CpG}$ islands within housekeeping gene promoters expressed in most tissues [74]. Large numbers of TFBS sites were observed for most of the human ITB 
genes examined, including 51, 56 and 105 such sites for ITB4, ITB6 and ITB8, respectively. Of particular significance for the human ITB1 and ITB3 gene promoters is the transcription factor, HoxD3, that binds directly to these promoters and assists in regulating the expression of integrins $\alpha 5 \beta 1$ and $\alpha \mathrm{V} \beta 3$ during angiogenesis [75]; the PPAR $\alpha$ (peroxisome proliferator-activated receptor- $\alpha$ ) that regulates gene expression in vascular cells and inhibits TGF (transforming growth factor)- $\beta$-induced ITB5 transcription [76] and Hox A10, that directs the regulation of the ITB3 gene in human endometrial cells and regulates transcription of ITB3 during myeloid differentiation [77-78]. Moreover, the genes encoding the integrin subunits $\beta 7, \beta 3, \beta 6$ and $\beta 8$ map to $12 \mathrm{q} 13.13,17 \mathrm{q} 21.32,2 \mathrm{q} 23-\mathrm{q} 31$ and $7 \mathrm{p} 15-\mathrm{p} 21$ positions respectively which are close to $H O X C, H O X B, H O X D$ and $H O X A$ genes suggesting a common divergence of these genes during vertebrate evolution [79].

Table 2. Predicted transcription factor binding sites (TFBS), $\mathrm{CpG}$ islands and MiRNA (MiR) regions for human and mouse ITB Genes. The human and mouse genome browsers (http://genome.ucsc.edu) [45] were used to examine the predicted transcription factor binding sites (TFBS), CpG islands and Mi-RNA binding sites for human and mouse ITB genes.

\begin{tabular}{|c|c|c|c|c|c|c|c|c|}
\hline Animal & Species & $\begin{array}{l}\text { Integrin } \\
\text { Beta } \\
\text { Gene }\end{array}$ & $\begin{array}{l}\text { Other } \\
\text { Gene } \\
\text { Name }\end{array}$ & $\begin{array}{l}\text { CpG } \\
\text { Islands }\end{array}$ & TFBS & $\begin{array}{l}\text { MiR-Sites } \\
\text { 3' region }\end{array}$ & $\begin{array}{l}\text { Expression } \\
\text { Level } \\
\text { (x average) }\end{array}$ & $\begin{array}{l}\text { Major } \\
\text { Tissue } \\
\text { Expression }\end{array}$ \\
\hline \multirow[t]{8}{*}{ Human } & $\begin{array}{l}\text { Homo } \\
\text { sapiens }\end{array}$ & ITBI & $I T G B I$ & CpG:158 & 39 & 8 & 6.1 & wide expression \\
\hline & & ITB2 & $I T G B 2$ & CpG18,21,22 & 7 & 0 & 3.8 & $\begin{array}{l}\text { thymus, spleen, } \\
\text { bone }\end{array}$ \\
\hline & & ITB3 & ITGB3 & CpG92 & 10 & 5 & 1.4 & $\begin{array}{l}\text { placenta, kidney, } \\
\text { skin }\end{array}$ \\
\hline & & ITB4 & ITGB4 & CpG19,22,62,91 & 51 & 2 & 4.6 & $\begin{array}{l}\text { colon, ovary, } \\
\text { pancreas }\end{array}$ \\
\hline & & ITB5 & ITGB5 & CpG152 & 47 & 0 & 4.5 & lung, ovary, kidney \\
\hline & & ITB6 & ITGB6 & 0 & 56 & 0 & 1.3 & $\begin{array}{l}\text { pancreas, lung, } \\
\text { kidney }\end{array}$ \\
\hline & & ITB7 & ITGB7 & CpG48 & 20 & 0 & 0.8 & leukocytes, spleen \\
\hline & & ITB8 & ITGB8 & CpG133 & 105 & 35 & 2.2 & wide expression \\
\hline \multirow[t]{9}{*}{ Mouse } & $\begin{array}{l}\text { Mus } \\
\text { musculus }\end{array}$ & Itbl & Itgbl & CpG120 & na & 3 & 2.0 & wide expression \\
\hline & & $I t b 2$ & Itgb2 & 0 & na & 0 & 1.6 & $\begin{array}{l}\text { thymus, spleen, } \\
\text { bone }\end{array}$ \\
\hline & & Itb2l & Itgb2l & 0 & na & 0 & 0.3 & bone marrow \\
\hline & & $I t b 3$ & $\operatorname{Itg} 33$ & CpG522 & na & 3 & 0.5 & spleen, placenta \\
\hline & & Itb4 & Itgb4 & CpG38,59 & na & 1 & 1.8 & mammary, brain \\
\hline & & Itb5 & Itgb5 & CpG87 & na & - & 3.7 & mammary, lung \\
\hline & & Itb6 & Itgb6 & 0 & na & 1 & 0.4 & $\begin{array}{l}\text { kidney, bladder, } \\
\text { heart }\end{array}$ \\
\hline & & $I t b 7$ & $\operatorname{Itg} b 7$ & CpG26 & na & 0 & 1.1 & spleen, mammary \\
\hline & & $I t b 8$ & $\operatorname{Itg} b 8$ & CpG316 & na & 2 & 1.2 & mammary, kidney \\
\hline
\end{tabular}


Several microRNA (miRNA) binding sites within the 3'-untranslated region (3'-UTR) of human ITB mRNA were also identified (Table 2). These microRNA species are phylogenetically conserved and regulate mRNA and protein expression during embryonic development [80-81]. MiRNA 183, for example, inhibits tumor invasiveness and participates in the development and function of neurosensory organs by targeting the ITBI (mRNA) gene [82] whereas ITB3 gene expression is apparently regulated by miRNA let-7a in malignant melanoma [83]. Over-expression of mir-124 attenuates endogenous ITB1 expression in oral squamous cell carcinomas [84] while microRNA miR-93 promotes tumor growth and angiogenesis by decreasing ITB8 transcripts [85]. The number of microRNAs that target the 3' UTR of human ITB transcripts (4 for ITB1, 44 for ITB2, 5 for ITB3, 1 for ITB 4, 53 for ITB5, 11 for ITB6, 30 for ITB7 and 2 for ITB8) varies widely among the human ITB genes examined. The absence of redundancy among this wide range of microRNA species regulating the levels of human integrin subunits suggests that the evolution of the $C$-terminal non-coding regions of these subunits followed a divergent path for the purpose of regulating the levels of expressions of each ITB subunits in different cells. The regulation of ITB4 by a single microRNA further suggests that the expression of this subunit is not intensely regulated at the post-transcriptional stage in comparison with the other human ITB genes.

Brendle and coworkers [86] have also examined single nucleotide polymorphisms (SNPs) in predicted miRNA sites for several ITA and ITB genes and the potential association of these SNPs with breast cancer risk (BCR) and reported a potential BCR marker for one of the ITB4 miRNA binding sites. A likely mechanism for mi-RNA translational regulation has been recently reported [87]. MicroRNAs have been shown to be transcribed as long primary-miRNAs (pri-miRNAs) in the nucleus and processed in the cytoplasm into 19-22 bp mature mi-RNAs which anneal to the 3'-UTR of target mRNAs to promote degradation or translational repression [88]. Moreover, considerable flexibility has been reported for mi-RNAs which are capable of targeting hundreds of genes while individual 3'-UTR mi-RNA regions may be a target for several distinct mi-RNAs [89-90]. The miRNA sequences within the 3'-UTR of human ITB genes are therefore likely to play a major role in regulating the translation of these genes within vertebrate tissues.

\subsection{Comparative Human and Mouse ITB Tissue Expression}

Figure 5 presents 'heat maps' showing comparative Itb gene expression for various mouse tissues obtained from GNF Expression Atlas Data using GNF1M chips (http://genome.ucsc.edu; http://biogps.gnf.org) [91]. These data supported a broad and high level tissue expression for mouse $I t b 7$, including during early embryonic development. A very high level of expression for Itb2 and Itb7 in bone marrow, spleen and lymphocytes are consistent with their involvement in forming the integrin receptors in blood cells [92]. The Itb4 expression was highest in epidermal tissues and is consistent with its presence in the hemidesmosomes of these epithelial cells [93-94]. It may be noted that ITB4 pairs only with the $\alpha 6$ subunit forming a laminin-binding receptor providing stable adhesion of epithelial cells with the basement membrane [95-96]. Other comparisons of mouse Itb tissue expression indicated significant differences, including higher levels of Itb3 expression in bone but with lower expression levels for Itb8 in most tissues examined. Overall, mouse Itb tissue expressions levels were up to 3.7 times the average level of gene expression [57] which supported key roles played by 
these membrane receptor proteins which serve various cell adhesion roles in tissue repair, hemostasis, immune response, embryogenesis and metastasis [92]. Similar tissue distribution profiles for ITB gene expression were observed for human tissues, including an overall high level gene expression ranging from 0.8-6.1 times the average level of human gene expression (Table 2).

Figure 5. Comparative tissue expression for mouse beta integrin genes (ITB). Expression 'heat maps' (GNF Expression Atlas 2 data) (http://biogps.gnf.org) [91] were examined for comparative gene expression levels among human and mouse tissues for ITB genes showing high (red); intermediate (black); and low (green) expression levels; derived from mouse genome browsers (http://genome.ucsc.edu) [45].

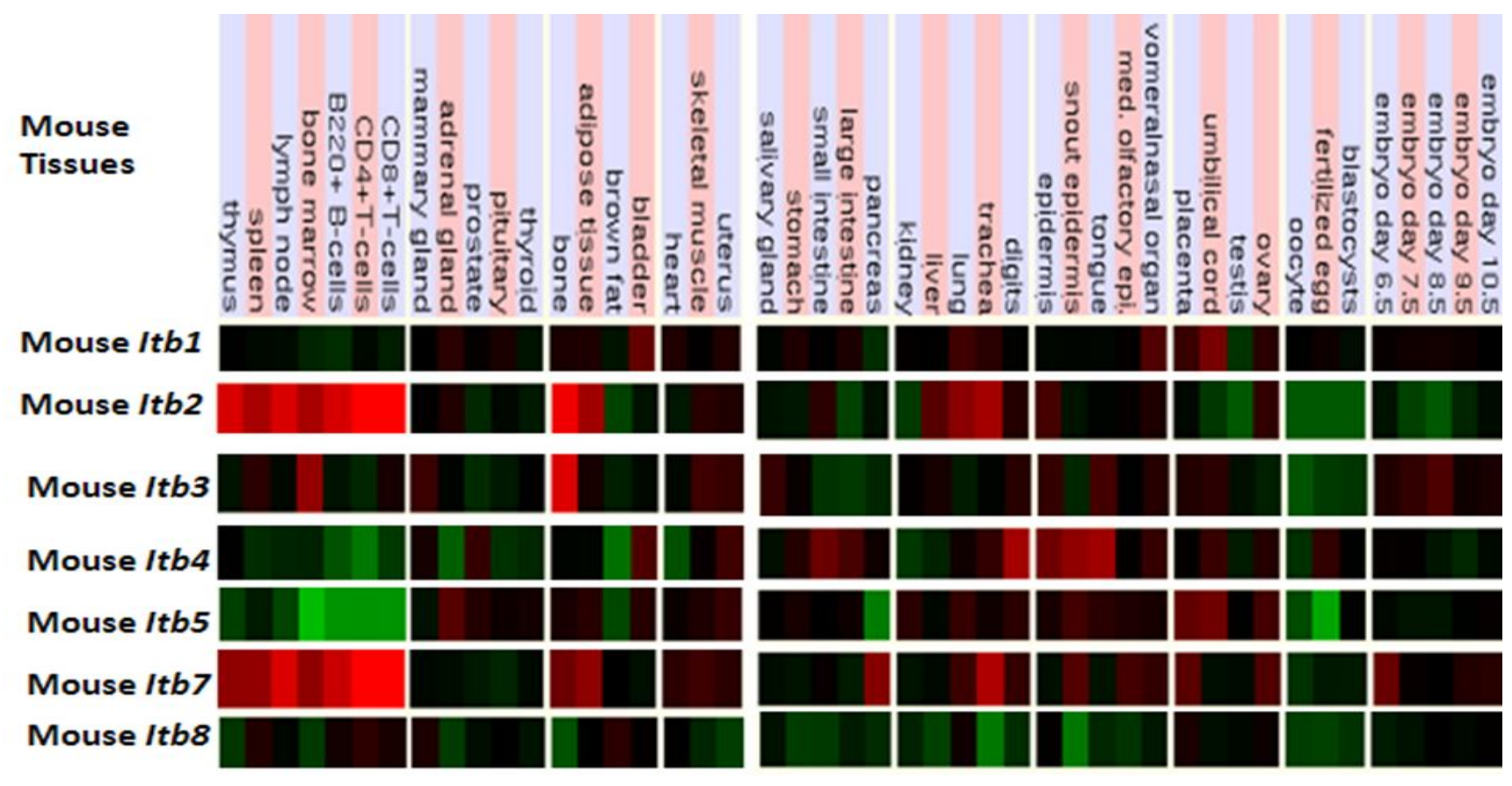

\subsection{Evolution of Vertebrate ITB Genes and Proteins}

A phylogenetic tree (Figure 6) was calculated by the progressive alignment of 61 vertebrate ITB amino acid sequences with vertebrate ITB1-8 sequences which was rooted with the Caenorhabitis elegans (nematode) ITB-like sequence (see Table 1). The phylogram showed clustering of the ITB sequences into groups which were consistent with their evolutionary relatedness, as well as groups for each of vertebrate ITB1-ITB8 which were distinct from the nematode ITB-like sequence. These groups were significantly different from each other (with bootstrap values of $>90$ ) and showed closer relatedness for the following ITB gene groupings: group 1: ITB1-ITB2-ITB7; group 2: vertebrate ITB4 with the elegans ITB-like sequence (PAT3); group 3: ITB3-ITB5-ITB6; and group 4: ITB8, which is the most distinct group in terms of its relatedness to other ITB gene families. It is apparent from this study of vertebrate ITB genes and proteins that these are ancient proteins for which a proposed common ancestor for the ITB genes may have predated the appearance of fish >500 millions of years ago [96].

Among the ITB integrin genes examined, the ITB4 integrin subunit gene related most closely with the $C$. elegans (nematode) PAT3 sequence indicating that it may represent the primordial vertebrate beta integrin gene and the first to appear in the vertebrate ancestor. The ITB4 differs from other ITB 
subunits. It is unusually longer (1778 residues) compared with other integrin $\beta$ subunits and contains a long amino-terminal (683 aa) and cytosolic (1072 aa) domains [33]. The extracellular domains of $\beta 4$ subunit showed low identity $(\sim 35 \%)$ with other $\beta$ integrin subunits. Moreover, the transmembrane domain of the ITB4 subunit is poorly conserved and is exceptionally long [92,97-98].

Figure 6. Phylogenetic tree of vertebrate beta integrin cytosolic domain amino acid sequences. The tree is labeled with the ITB name and the name of the animal and is 'rooted' with the Caenorhabitis elegans (nematode) ITB-like sequence (see Table 1). Note the 7 major clusters corresponding to the ITB1, ITB2, ITB3, ITB4, ITB5, ITB6, ITB7 and ITB8 gene families. A genetic distance scale is shown (\% amino acid substitutions). The number of times a clade (sequences common to a node or branch) occurred in the bootstrap replicates are shown. Only replicate values of 90 or more which are highly significant are shown with 100 bootstrap replicates performed in each case.
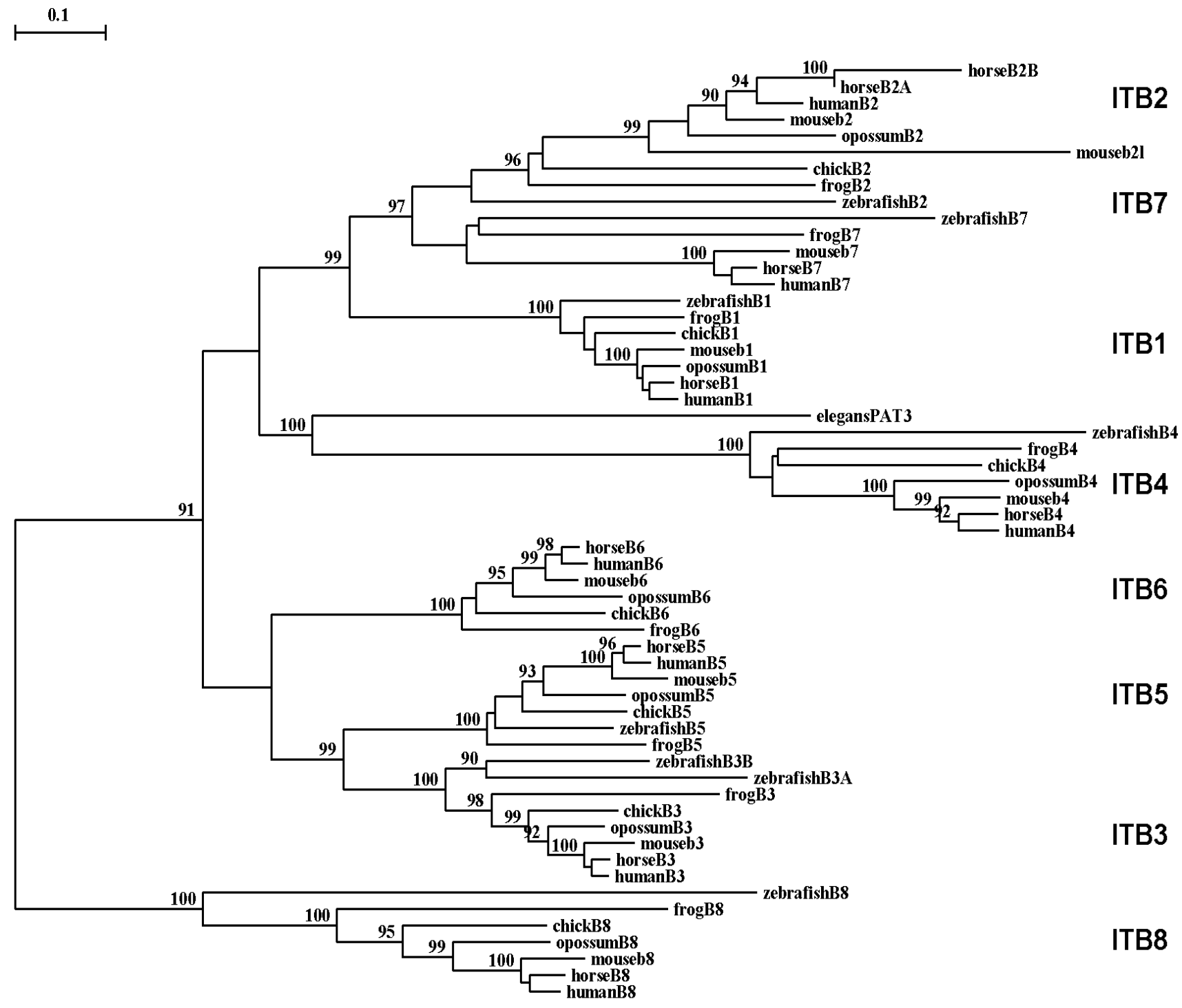


\subsection{Vertebrate ITB Integrins: Functional and Comparative Aspects}

Different integrin beta receptor proteins are known to interact with at least 22 different ligands and matrix proteins $[14,92,99-102]$ that are summarized in Table 3. Of these, ITB1 pairs with the largest number of ligands (12 ligands) followed by ITB2 and ITB3 (7 ligands each), ITB5, ITB6 and ITB7 (3 ligands each), ITB8 (2 ligands) and ITB4 (1 ligand). Moreover, ITB1 pairs with the largest number of $\alpha$ subunits (fourteen) followed by ITB2 (four), ITB3 and ITB7 (two), and ITB4, ITB5, ITB6 and ITB8 (single $\alpha$ subunit). The ITB4 subunit pairs only with the ITA6 subunit forming $\alpha 6 \beta 4$ as the sole integrin receptor of the hemidesmosomes, a structural component, that is required for the attachment of cells with the basal lamina [103-105]. The genes and proteins of hemidesmosomes [107] date back to metazoans/holozoans, suggesting that the attachment of unicellular life forms on the basal lamina via the hemidesmosomes possibly initiated the formation of multicellular organisms with the evolution of other cell-cell junction components (tight, adherent, desmosmal and gap junctions). The tissue specific expression of integrin ITB subunits (Figure 6) showed that mammalian Type I hemidesmosomes are found in the epithelial cells of skin, mouth and esophagus whereas Type II hemidesmosomes are found in the intestinal epithelial cells [93]. This is consistent with the high expression of ITB4 in epithelial cells. While the ITB4 subunit in the $\alpha 6 \beta 4$ integrin receptor primarily plays a role in the formation of stable adhesions of epithelial cells with laminin-332, recent studies have suggested an additional role in the migration of keratinocytes and cancer cells [106,108]. Prior to migration, keratinocytes lose their stable adhesion mediated by hemidesmosomes and migrate over collagen and then secrete a provisional matrix of laminin-332 for its motility [109]. The cancer cells also require laminin-332 to migrate [110]. It is now known that the proteolytic cleavage of laminin-332 triggers cell motility of cells via the $\alpha 6 \beta 4$ receptor [111]. Other evidence suggests that the migration on laminin-332 is indeed mediated by the $\alpha 3 \beta 1$ integrin rather than the $\alpha 6 \beta 4$ integrin which actually has transdominating inhibiting effects on migration mediated by the $\alpha 3 \beta 1$ integrin [112]. Overall these reports indicate that the ancestral role of integrin in forming stable adhesions of epithelial cells via hemidesmosome might have evolved to support migratory roles of cells by the introduction of additional integrin receptors to perform specialized functions. In this regard, the evolution of the ITB1 subunit from the primordial ITB4 may have played a significant role in influencing cell migration. The transmigration of blood cells across the endothelial layers, a highly specialized function mediated by the integrins, may be associated with the evolution of receptors $\alpha v \beta 3$ and those formed by the association of the ITB2 subunit with $\alpha \mathrm{L}, \alpha \mathrm{M}, \alpha \mathrm{X}$ or $\alpha \mathrm{D}$ subunits [113-119].

The extracellular domains of both $\alpha$ and $\beta$ subunits of a receptor interact with wide spectrum of ECM molecules (Table 3) to perform various cellular functions. This suggests that these receptors may have evolved along with the evolution of ECM molecules for performing diverse functions in the context of presence or absence of specific ligands. Consequently, the ITB1 subunit may be the most promiscuous of all of the vertebrate $\beta$ subunits as it pairs with the largest number of $\alpha$ subunits, and these alpha/beta1 heterodimers also interact with a large number of ligands. This is consistent with the observation that ITB1 like subunits had already diverged in the earlier stages of metazoans (corals and sponges) [120]. Therefore, the clues to the evolution of different vertebrate integrin receptors may lie in their evolution to interact with different ECM molecules. However, in the absence of comprehensive information on the different domains/motifs of the ECM molecules that interact with the specific 
domains of different integrin receptor, further conclusions may not be derived. Nevertheless, the clues to the evolutionary proximity amongst different $\beta$ subunits might be found in their ability to pair with common $\alpha$ subunit/s, since these $\beta$ subunits are likely to preserve domain/s that determine their ability to associate with similar $\alpha$ subunit/s or vice versa [121]. With this notion and based on the overlapping subunit compositions of functional integrin receptors (Figure 7), it is predicted that ITB1 that shares the sole alpha subunit ( $\alpha 6)$ with ITB4, is the closest to the ancestor ITB4. The ITB1 evolved to pair with the largest number of alpha subunits (Table 3) including $\alpha 4$ that is shared with ITB7, and the $\alpha$ v subunit that is shared with ITB3, ITB5, ITB6 and ITB8. Therefore, the cluster containing ITB3, ITB5, ITB6 and ITB8, and the cluster consisting of ITB7 and ITB2 may have been derived directly from ITB1. The origin of ITB5, ITB6 and ITB8 from ITB3 (rather from the versatile ITB1) is less likely because ITB3 is the most specialized of this cluster and is expressed in both blood cells (platelets) and other cell types such as placental trophoblast and cancer cells [122-124]. In contrast, ITB5, ITB6 and ITB8 including ITB1 are not expressed in blood cells. The ITB2 and ITB7 subunits, that constitute solely the integrins of hematopoietic and immune system [125], and specifically ITB2 that does not share an $\alpha$ subunit with other ITB subunits, are likely to be the most specialized ITB subunits. The $\alpha \mathrm{L} \beta 2$ mediates migration of T-Cells across the endothelium (invasion or transmigration) and the $\alpha 4 \beta 7$ expressed on memory $\mathrm{T}$ cells directs their trafficking to the sites of inflammation.

Table 3. Multiplicity and specificity of ligand binding by ITB subunits; ECM refers to extracellular matrix.

\begin{tabular}{|c|c|c|}
\hline ECM or Ligand & $\beta$ Integrin subunit & Integrin Receptor/s \\
\hline Collagens & $\beta 1$ & $\alpha 1 \beta 1, \alpha 2 \beta 1, \alpha 10 \beta 1, \alpha 11 \beta 1$ \\
\hline E-Cadherin & $\beta 1, \beta 7$ & $\alpha \mathrm{E} \beta 7, \alpha 2 \beta 1$ \\
\hline Endorepellin & $\beta 1$ & $\alpha 2 \beta 1$ \\
\hline Endostatin & $\beta 1$ & $\alpha 5 \beta 1$ \\
\hline Factor $\mathrm{X}$ & $\beta 2$ & $\alpha \mathrm{M} \beta 2$ \\
\hline Fibronectin & $\beta 1, \beta 2, \beta 3, \beta 6$ and $\beta 7$ & $\alpha 4 \beta 1, \alpha 5 \beta 1, \alpha 8 \beta 1, \alpha v \beta 1, \alpha \operatorname{IIb} \beta 3, \alpha v \beta 3, \alpha v \beta 6, \alpha 4 \beta 7, \alpha M \beta 2$ \\
\hline Fibrinogen & $\beta 2, \beta 3$ and $\beta 5$ & $\alpha \mathrm{M} \beta 2, \alpha \mathrm{X} \beta 2, \alpha \operatorname{IIb} \beta 3, \alpha v \beta 3, \alpha v \beta 5$ \\
\hline ICAM-1, $-2,-3,-5$ & $\beta 2$ & $\alpha \mathrm{L} \beta 2$ \\
\hline ICAM-3 & $\beta 2$ & $\alpha \mathrm{D} \beta 2$ \\
\hline $\mathrm{iC} 3 \mathrm{~b}$ & $\beta 2$ & $\alpha \mathrm{M} \beta 2, \alpha \mathrm{X} \beta 2$ \\
\hline Laminins & $\beta 1$ and $\beta 4$ & $\alpha 1 \beta 1, \alpha 2 \beta 1, \alpha 3 \beta 1, \alpha 6 \beta 1, \alpha 6 \beta 4, \alpha 7 \beta 1$, \\
\hline MadCAM-1 & $\beta 7$ & $\alpha 4 \beta 7$ \\
\hline Nephronectin (RGD) & $\beta 1$ & $\alpha 8 \beta 1$ \\
\hline Osteopontin & $\beta 1, \beta 3$ and $\beta 5$ & $\alpha v \beta 1, \alpha v \beta 3, \alpha v \beta 5$ \\
\hline Semaphorin 7A & $\beta 1$ & $\alpha 1 \beta 1$ \\
\hline Tenascin-C & $\beta 1, \beta 3$ and $\beta 6$ & $\alpha 1 \beta 1, \alpha 8 \beta 1, \alpha 9 \beta 1, \alpha v \beta 3$ and $\alpha v \beta 6$ \\
\hline TGF- $\beta$-LAP (RGD) & $\beta 6$ and $\beta 8$ & $\alpha v \beta 6, \alpha v \beta 8$ \\
\hline Tumastatin & $\beta 3$ & $\alpha v \beta 3$ \\
\hline VCAM-1 & $\beta 2$ and $\beta 7$ & $\alpha \mathrm{D} \beta 2, \alpha 4 \beta 7, \alpha \mathrm{H} \beta 7$ \\
\hline VEGF-C, VEGF-D & $\beta 1$ & $\alpha 9 \beta 1$ \\
\hline Vitronectin & $\beta 1, \beta 3, \beta 5$ and $\beta 8$ & $\alpha v \beta 1, \alpha 8 \beta 1, \alpha v \beta 3, \alpha v \beta 5, \alpha v \beta 8$, \\
\hline Von Willebrandt Factor & $\beta 3$ & $\alpha \operatorname{IIb} \beta 3, \alpha v \beta 3$ \\
\hline
\end{tabular}


An analysis of $\alpha$ subunit sharing by different ITB subunits suggests that evolution of the ITB1 subunit led to the emergence of two groups of ITB subunits, one consisting of ITB3, ITB5, ITB6 and ITB8 subunits and the other consisting of ITB7 and ITB2. This conclusion from the subunit sharing concept (Figure 7) is very similar to our phylogenetic analysis data that suggests that ITB1-ITB7-ITB2 belong to one cluster and the ITB3-ITB5-ITB6 as another cluster. A previous phylogenetic study on ITBs [16] supported ITB1-ITB7-ITB2 as one cluster and the ITB3- ITB5-ITB8 as another cluster. Therefore, two phylogenetic analyses differed by one subunit (ITB6/ITB8) in their second cluster but both found ITB4 either an outlier or an ancestral integrin subunit. The ITB8 is found to be a distinct member of ITBs in our study whereas in the previous study it was found to diverge from the ITB6 earlier in evolution. The subunit pairing concept (Figure 7), however, groups the ITB8 subunit belonging to cluster 2 of both studies together (ITB3-ITB5-ITB6-ITB8) which is consistent with a previous report [15].

Figure 7. The blue arrows show the predicted evolutionary paths of $\beta$ subunits from the ancestral $\beta 4$ subunit. Pairings of different $\alpha$ and $\beta$ subunits are shown by thin black lines. This concept shows two lines of evolution diverging from $\beta 1$, one towards blood cell integrins consisting of $\beta 2$ or $\beta 7$ subunits and the other towards a cluster consisting of $\beta 5$, $\beta 6, \beta 8$ and $\beta 3$ subunits that are primarily expressed in tissues other than blood with exception of $\alpha \mathrm{IIb} . \beta 3$ that is expressed also in blood platelets (see text).

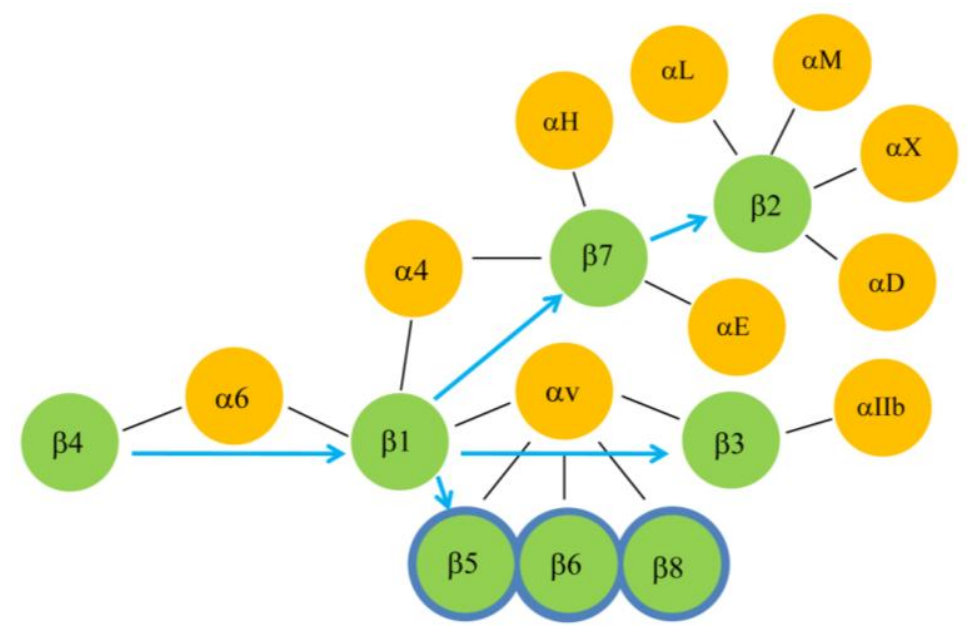

\section{Methods}

\subsection{Vertebrate ITB Gene and Protein Identification}

BLAST (Basic Local Alignment Search Tool) studies were undertaken using web tools from the National Center for Biotechnology Information (NCBI) (http://blast.ncbi.nlm.nih.gov/Blast.cgi) [127]. Protein BLAST analyses used human and mouse ITB amino acid sequences previously described (Table 1). Non-redundant protein sequence databases for several vertebrate genomes were examined using the blastp algorithm, including human (Homo sapiens) [128]; horse (Equus caballus) [129]; mouse (Mus musculus) [130]; opossum (Monodelphis domestica) [131]; chicken (Gallus gallus) [132]; frog (Xenopus tropicalis) (http://genome.jgi-psf.org/Xentr3/Xentr3.home.html); zebrafish (Danio rerio) (http://www.sanger.ac.uk/Projects/D_rerio/); and nematode (Caenorhabditis elegans) (http://genome.ucsc.edu/). This procedure produced multiple BLAST 'hits' for each of the protein 
databases which were individually examined and retained in FASTA format, and a record kept of the sequences for predicted mRNAs and encoded ITB-like proteins. These records were derived from annotated genomic sequences using the gene prediction method: GNOMON and predicted sequences with high similarity scores for human ITB. Predicted ITB-like protein sequences were obtained in each case and subjected to analyses of predicted protein and gene structures.

BLAT analyses were subsequently undertaken for each of the predicted ITB amino acid sequences using the UCSC Genome Browser (http://genome.ucsc.edu/cgi-bin/hgBlat) [45] with the default settings to obtain the predicted locations for each of the mammalian ITB genes, including predicted exon boundary locations and gene sizes. Structures for human and mouse isoforms (splicing variants) were obtained using the AceView website to examine predicted gene and protein structures (http://www.ncbi.nlm.nih.gov/IEB/Research/Acembly/index.html?human) [57].

\subsection{Prediction of Signal Peptide Sequence and the Secondary Structure of Human Vertebrate ITB Proteins}

FASTA sequence of different human $\beta$ integrin amino acid sequences were subjected to SignalP 3.0 Server (http://www.cbs.dtu.dk/services/SignalP) [133] to determine the number of amino-acids and the predicted secondary structures in the $N$-terminal end of the ITGB isoform involved in the formation of the signal peptide. The secondary structures of each signal peptide were determined using a SWISSMODEL workspace (http://swissmodel.expasy.org) [134].

\subsection{Predicted Structures and Properties of the Cytoplasmic Domains of Vertebrate Beta Integrins}

Predicted secondary and tertiary structures for the predicted cytoplasmic domains of vertebrate ITB-like proteins were obtained using the SWISS MODEL web tools [134]. The tertiary structures of the cytoplasmic tails for human ITB1 [residues 1-36], ITB2 [residues 1-47] and ITB7 [residues 1-38] were predicted using a model (PDB: $3 \mathrm{~g} 9 \mathrm{wC}$ ) for human ITB1 [135]; while the reported structure for human ITB3 [136] (PDB:1m8oB) served as the reference for human ITB3 (residues 1-47), ITB5 (residues 1-40) and ITB6 (residues 1-45) tertiary structures, and the human ITB4 structure (PDB: 2yrzA) [137] for human ITB4 (residues 906-1007). Theoretical isoelectric points and molecular weights for vertebrate ITB-like proteins were obtained using Expasy web tools (http://au.expasy.org/tools/pi_tool.html).

\subsection{Comparative Human Beta Integrin (ITB) Expression}

The UCSC Genome Browser (http://genome.ucsc.edu) [45] was used to examine GNF Expression Atlas 2 data using various expression chips for human ITB genes (http://biogps.gnf.org) [91]. Gene array expression 'heat maps' were examined for comparative gene expression levels among human and mouse tissues showing high (red); intermediate (black); and low (green) expression levels.

\subsection{Comparative CpG Islands, Transcription Factor Binding Sites (TFBS) and microRNA Sequences of Human Beta Integrin Genes (ITB)}

The UCSC Human Genome Browser (http://genome.ucsc.edu) [45] was used to examine the comparative location, number and sequences for human $\mathrm{CpG}$ islands, transcription factor binding sites 
(TFBS) and microRNA sites located in the 3'-untranslated region (UTR) of human ITB genes in association with the TargetScan website (http://www.targetscan.org).

\subsection{Phylogeny Studies and Sequence Divergence}

Alignments of vertebrate ITB-like and nematode (Caenorhabditis elegans) PAT3 protein sequences were assembled using BioEdit v.5.0.1 and the default settings [137]. Alignment ambiguous regions were excluded prior to phylogenetic analysis yielding alignments of 370 residues for comparisons of vertebrate ITB sequences with the nematode PAT3 (beta-integrin homolog) sequence (Table 1). Evolutionary distances were calculated using the Kimura option [138] in TREECON [139]. Phylogenetic trees were constructed from evolutionary distances using the neighbor-joining method [140] and rooted with the nematode PAT3 sequence. Tree topology was reexamined by the boot-strap method (100 bootstraps were applied) of resampling and only values that were highly significant ( $\geq 90)$ are shown [141].

\section{Conclusions}

Bioinformatic analyses of the integrin genes and proteins in vertebrates revealed a high degree of diversity in terms of their chromosome locations, alternate splicing, transcriptional and post-transcriptional regulations, and tissue specific expressions. Results suggested that the evolution of integrins within vertebrates followed a divergent path for these genes and protein structures but with common functions specializing towards adhesion, migration and transmigration of cells in succession. Our phylogenetic analysis revealed for the first time that ITB4 (encoding the $\beta 4$ integrin) is the most likely ancestral form of integrin $\beta$-like genes. This subunit has inherited the ancestral role for $\beta$-integrins in forming simple adhesions (hemidesmosomes) in vertebrate cells similar to unicellular organism and is also involved in the migration of transformed (cancer) cells [7]. The subunit sharing analysis of ITB subunits reveals that $\beta 2$ and $\beta 7$ subunits that are expressed only in the cells of hematopoietic and immune system are possibly the most specialized forms of integrins.

\section{Acknowledgements}

This project was supported by a research grant (RR017701) from the Center for Psychiatric Neuroscience, UMMC to UKR. We also acknowledge the expert assistance of Bharet Patel of Griffith University with the phylogeny studies.

\section{References}

1. Schmid, R.S.; Anton, E.S. Role of integrins in the development of the cerebral cortex. Cereb. Cortex 2003, 13, 219-224.

2. Linask, K.K.; Manisastry, S.; Han, M. Cross talk between cell-cell and cell-matrix adhesion signalling pathways during heart organogenesis: Implications for cardiac birth defects. Microsc. Microanal. 2005, 11, 200-208.

3. Denda, S.; Reinhardt, L.F. Studies on integrins in the nervous system. Meth. Enzymol. 2007, 426, 203-221. 
4. Manso, A.M.; Kang, S.M.; Ross, R.S. Integrins, focal adhesions and cardiac fibroblasts. J. Investig. Med. 2009, 57, 856-860.

5. Kim, C.; Ye, F.; Ginsberg, M.H. Regulation of Integrin Activation. Annu. Rev. Cell Dev. Biol. 2011, 27, 1-7

6. Pulina, M.V.; Hou, S.Y.; Mittal, A.; Julich, D.; Whittaker, C.A.; Holley, S.A.; Hynes, R.O.; Astrof, S. Essential roles of fibronectin in the development of the left-right embryonic body plan. Dev. Biol. 2011, 354, 208-220.

7. Wickstrom, S.A.; Radovanac, K.; Fassler, R. Genetic analyses of integrin signaling. Cold Spring Harbor Persp. Biol. 2011, doi: 10.1101/cshperspect.a005116.

8. Chen, C.; Sheppard, D. Identification and molecular characterization of multiple phenotypes in integrin knockout mice. Meth. Enzymol. 2007, 426, 291-305.

9. Weiss, L.A.; Kosova, G.; Delahunty, R.J.; Jiang, L.; Cook, E.H.; Ober, C.; Sutcliffe, J.S. Variation in ITGB3 is associated with whole-blood serotonin level and autism susceptibility. Eur. J. Hum. Genet. 2006, 14, 923-931.

10. Pillitteri, D.; Pilgrimm, A.K.; Kirchmaier, C.M. Novel mutations in the GPIIb and GPIIa genes in Glanzmann Thrombobastenia. Transfusion Med. Hemotherapeutics 2010, 37, 268-277.

11. Wang, W.; Luo, B.H. Structural basis of integrin transmembrane activation. J. Cell Biochem. 2010, 109, 447-452.

12. Anthis, N.J.; Campbell, I.D. The tail of integrin activation. Trends Biochem. Sci. 2011, 36, 191-198.

13. Qin, J.; Vinogradova, O.; Plow, E.F. Integrin bidirectional signaling: a molecular view. PLoS Biol. 2004, 2, e169.

14. Hynes, R.O. Integrins: Bidirectional, allosteric signaling machines. Cell 2002, 110, 673-687.

15. Burke, R.D. Invertebrate integrins: Structure, function, and evolution. Int. Rev. Cytol. 1999, 191, 257-284.

16. Hughes, A.L. Evolution of the integrin alpha and beta protein families. J. Mol. Evol. 2001, 52, 63-72.

17. Ewan, R.; Huxley-Jones, J.; Mould, A.P.; Humphries, M.J.; Robertson, D.L.; Boot-Handford, R.P. The integrins of the urochordate Ciona intestinalis provide novel insights into the molecular evolution of the vertebrate integrin family. BMC Evol. Biol. 2005, 5, 31.

18. Sebe-Pedros, A.; Roger, A.J.; Lang, F.B.; King, N.; Ruiz-Trillo, I. Ancient origin of the integrinmediated adhesion and signaling machinery. Proc.Natl. Acad. Sci. USA 2010, 107, 10142-10147.

19. Sebe-Pedros, A.; Ruiz-Trillo, I. Integrin-mediated adhesion complex: Cooption of signaling systems at the dawn of Metazoa. Commun. Integrin Biol. 2010, 3, 475-477.

20. Hedges, S.B. The origin and evolution of model organisms. Nature 2002, 3, 838-849.

21. Argraves, W.S.; Suzuki, S.; Arai, H.; Thompson, K.; Pierschbacher, M.D.; Ruoslahti, E. Amino acid sequence of the human fibronectin receptor. J. Cell Biol. 1987, 105, 1183-1190.

22. Balzac, F.; Belkin, A.M.; Koteliansky, V.E.; Balabanov, Y.V.; Altruda, F.; Silengo, L.; Tarone, G. Expression and functional analysis of a cytoplasmic domain variant of the beta 1 integrin subunit. J. Cell Biol. 1993, 121, 171-178.

23. Altruda, F.; Cervella, P.; Tarone, G.; Botta, C.; Balzac, F.; Stefanuto, G.; Silengo, L. A human integrin beta 1 subunit with a unique cytoplasmic domain generated by alternative mRNA processing. Gene 1990, 95, 261-266. 
24. Zhidkova, N.I.; Belkin, A.M.; Mayne, R. Novel isoform of beta 1 integrin expressed in skeletal and cardiac muscle. Biochem. Biophys. Res. Comm. 1995, 214, 279-285.

25. Kishimoto, T.K.; O'Connor, K.; Lee, A.; Roberts, T.M.; Springer, T.A. Cloning of the beta subunit of the leukocyte adhesion proteins: homology to an extracellular matrix receptor defines a novel supergene family. Cell 1987, 48, 681-690.

26. Weitzman, J.B.; Wells, C.E.; Wright, A.H.; Clark, P.A.; Law, S.K.A. The gene organisation of the human beta 2 integrin subunit (CD18). FEBS Lett. 1991, 294, 97-103.

27. Konstandin, M.H.; Aksoy, H.; Wabnitz, G.H.; Volz, C.; Erbel, C.; Kirchgessner, H.; Giannitsis, E.; Katus, H.A.; Samstag, Y.; Dengler, T.J. Beta2-integrin activation on T cell subsets is an independent prognostic factor in unstable angina pectoris. Basic. Res. Cardiol. 2009, 104, 341-351.

28. Fitzgerald, L.A.; Steiner, B.; Rall, S.C., Jr.; Lo, S.; Phillips, D.R. Protein sequence of endothelial glycoprotein IIIa derived from a cDNA clone. Identity with platelet glycoprotein IIIa and similarity to 'integrin'. J. Biol. Chem. 1987, 262, 3936-3939.

29. Zimrin, A.B.; Eisman, R.; Vilaire, G.; Schwartz, E.; Bennett, J.S.; Poncz, M. Structure of platelet glycoprotein IIIa. A common subunit for two different membrane receptors. J. Clin. Investig. 1988, 81, 1470-1475.

30. Rosa, J.P.; Bray, P.F.; Gayet, O.; Johnston, G.I.; Jackson, K.W.; Shuman, M.A.; McEver, R.P. Cloning of glycoprotein IIIa cDNA from human erythroleukemia cells and localization of the gene to chromosome 17. Blood 1988, 72, 593-600.

31. Kumar, C.S.; James, I.E.; Wong, A.; Mwangi, V.; Field, J.A.; Nuthulaganti, P.; Connor, J.R.; Eichman, C.; Ali, F.; Hwang, S.M.; Rieman, D.J.; Drake, F.H.; Gowen, M. Cloning and characterization of a novel integrin beta3 subunit. J. Biol. Chem. 1997, 272, 16390-16397.

32. Suzuki, S.; Naitoh, Y. Amino acid sequence of a novel integrin beta 4 subunit and primary expression of the mRNA in epithelial cells. EMBO J. 1990, 9, 757-763.

33. Hogervorst, F.; Kuikman, I.; von Dem Borne, A.E.G.K.; Sonnenberg, A. Cloning and sequence analysis of beta-4 cDNA: An integrin subunit that contains a unique $118 \mathrm{kd}$ cytoplasmic domain. EMBO J. 1990, 9, 765-770.

34. Iacovacci, S.; Gagnoux-Palacios, L.; Zambruno, G.; Meneguzzi, G.; D'Alessio, M. Genomic organization of the human integrin beta 4 gene. Mamm. Genome 1997, 8, 448-450.

35. Ramaswamy, H.; Hemler, M.E. Cloning, primary structure and properties of a novel human integrin beta subunit. EMBO J. 1990, 9, 1561-1568.

36. Suzuki, S.; Huang, Z.S.; Tanihara, H. Cloning of an integrin beta subunit exhibiting high homology with integrin beta 3 subunit. Proc. Natl. Acad. Sci. USA 1990, 87, 5354-5358.

37. McLean, J.W.; Vestal, D.J.; Cheresh, D.A.; Bodary, S.C. cDNA sequence of the human integrin beta 5 subunit. J. Biol. Chem. 1990, 265, 17126-17131.

38. Sheppard, D.; Rozzo, C.; Starr, L.; Quaranta, V.; Erle, D.J.; Pytela, R. Complete amino acid sequence of a novel integrin beta subunit (beta 6) identified in epithelial cells using the polymerase chain reaction. J. Biol. Chem. 1990, 265, 11502-11507.

39. Jiang, W-M.; Jenkins, D.; Yuan, Q.; Leung, E.; Choo, K.H.; Watson, J.D.; Krissansen, G.W. The gene organization of the human beta 7 subunit, the common beta subunit of the leukocyte integrins HML-1 and LPAM-1. Int. Immunol. 1992, 4, 1031-1040. 
40. Fontana, L.; Chen, Y.; Prijatelj, P.; Sakai, T.; Fassler, R.; Sakai, L.Y.; Rifkin, D.B. Fibronectin is required for integrin alphavbeta6-mediated activation of latent TGF-beta complexes containing LTBP-1. FASEB J. 1990, 19, 1798-1808.

41. Yuan, Q.; Jiang, W-M.; Krissansen, G.W.; Watson, J.D. Cloning and sequence analysis of a novel beta 2-related integrin transcript from $\mathrm{T}$ lymphocytes: homology of integrin cysteine-rich repeats to domain III of laminin B chains. Int. Immunol. 1990, 2, 1097-1108.

42. Erle, D.J.; Rueegg, C.; Sheppard, D.; Pytela, R. Complete amino acid sequence of an integrin beta subunit (beta 7) identified in leukocytes. J. Biol. Chem. 1991, 266, 11009-11016.

43. Moyle, M.; Napier, M.A.; McLean, J.W. Cloning and expression of a divergent integrin subunit beta 8. J. Biol. Chem. 1991, 266, 19650-19658.

44. Hillier, L.W.; Fulton, R.S.; Fulton, L.A.; Graves, T.A.; Pepin, K.H.; Wagner-McPherson, C.; Layman, D.; Maas, J.; Jaeger, S.; Walker, R.; et al. The DNA sequence of human chromosome 7. Nature 2003, 424, 157-164.

45. Kent, W.J.; Sugnet, C.W.; Furey, T.S. The human genome browser at UCSC. Genome Res. 2003, 12, 994-1006.

46. Jornvall, H.; Hőőg, J.-O.; Persson, B.; Parés, X. Pharmacogenetics of the alcohol dehydrogenase system. Pharmacology 2000, 61, 184-191.

47. Holmes, R.S.; Goldberg, E. Computational analyses of mammalian lactate dehydrogenases: human, mouse, opossum and platypus LDHs. Comput. Biol. Chem. 2009, 33, 379-385.

48. Shanthalingam, S.; Srikumaran, S. Intact signal peptide of CD18, the $\beta$-subunit of $\beta_{2}$-integrins, renders ruminants susceptible to Mannheimia haemolytica leukotoxin. Proc. Natl. Acad. Sci. USA 2009, 106, 15448- 15453.

49. Williams, E.J.; Pal, C.; Hurst, L.D. The molecular evolution of signal peptides. Gene 2000, 253, 313-322.

50. Goldstein, J.; Lehnhardt, S.; Inouye, M. Enhancement of protein translocation across the membrane by specific mutations in the hydrophobic region of the signal peptide. J. Bacteriol. 1990, 172, 1225-1231.

51. Hatsuzawa, K.; Tagaya, M.; Mizushima, S. The hydrophobic region of signal peptides is a determinant for SRP recognition and protein translocation across the ER membrane. J. Biochem. 1997, 121, 270-277.

52. Marchler-Bauer, A.; Lu, S.; Anderson, J.B.; Chitsaz, F.; Derbyshire, M.K.; DeWeese-Scott, C.; Fong, J.H.; Geer, L.Y.; Geer, R.C.; Gonzales, N.R.; et al. CDD: A Conserved Domain Database for the functional annotation of proteins. Nucleic Acids Res. 2011, 39(D), 225-229.

53. Alonso-García, N.; Inglés-Prieto, A.; Sonnenberg, A.; de Pereda, J.M. (2009) Structure of the Calx-beta domain of the integrin beta4 subunit: Insights into function and cation-independent stability. Acta Crystallogr. D Biol. Cryst. 2009, 65, 858-871.

54. Ali, O.; Guillou, H.; Destaing, O.; Albiges-Rizo, C.; Block, M.R.; Fourcade, B. Cooperativity between integrin activation and mechanical stress leads to integrin clustering. Biophys. J. 2011, 100, 2595-2604.

55. Su, L.; Xin, L.; Miao, J.Y. Integrin $\beta 4$ in neural cells. Neuromol. Med. 2008, 10, 316-321. 
56. Ali, O.; Guillou, H.; Destaing, O.; Albiges-Rizo, C.; Block, M.R.; Fourcade, B. Cooperativity between integrin activation and mechanical stress leads to integrin clustering. Biophys. J. 2011, 100, 2595-2604.

57. Thierry-Mieg, D.; Thierry-Mieg, J. AceView: A comprehensive cDNA-supported gene and transcripts annotation. Genome Biol. 2006, 7, S12.

58. Tarone, G.; Hirsch, E.; Brancaccio, M.; De Acetis, M.; Barberis, L.; Balzac, F.; Retta, S.F.; Botta, C.; Altruda, F.; Silengo, L. Integrin function and regulation during development. Int. J. Dev. Biol. 2000, 44, 725-731.

59. Marcantonio, E.E.; Guan, J.L.; Trevithick, J.E.; Hynes, R.O. Mapping of the functional determinants of the integrin beta 1 cytoplasmic domain by site-directed mutagenesis. Cell Regul. 1990, 1, 597-604.

60. Chang, D.D.; Wong, C.; Smith, H.; Liu, J. ICAP-1, a novel beta1 integrin cytoplasmic domainassociated protein, binds to a conserved and functionally important NPXY sequence motif of beta1 integrin. J. Cell Biol. 1997, 138, 1149-1157.

61. Tadokoro, S.; Shattil, S.J.; Eto, K.; Tai, V.; Liddington, R.C.; de Pereda, J.M.; Ginsberg, M.H.; Calderwood, D.A. Talin binding to integrin beta tails: a final common step in integrin activation. Science 2003, 302, 103-106.

62. Vignoud, L.; Albiges-Rizo, C.; Frachet, P.; Block, M.R. NPXY motifs control the recruitment of the alpha5beta1 integrin in focal adhesions independently of the association of talin with the beta1 chain. J. Cell Sci. 1997, 110, 1421-1430.

63. Reszka, A.A.; Hayashi, Y.; Horwitz, A.F. Identification of amino acid sequences in the integrin $\beta 1$ cytoplasmic domain implicated in cytoskeletal association. J. Cell Biol. 1992, 117, 1132-1130.

64. O'Toole, T.E.; Mandelman, D.; Forsyth, J.; Shattil, S.J.; Plow, E.F.; Ginsberg, M.H. Modulation of the affinity of integrin alpha IIb beta 3 (GPIIb-IIIa) by the cytoplasmic domain of alpha IIb. Science 1991, 254, 845-847.

65. Ma, YQ.; Yang, J.; Pesho, M.M.; Vinogradova, O.; Qin, J.; Plow, E.F. Regulation of integrin alphallbbeta3 activation by distinct regions of its cytoplasmic tails. Biochemistry 2006, 45, 6656-6662.

66. Chang, D.D.; Hoang, B.Q.; Liu, J.; Springer, T.A. Molecular basis for interaction between Icap1 alpha PTB domain and beta 1 integrin. J. Biol. Chem. 2002, 277, 8140-8147.

67. Calderwood, D.W.; Fujioka, Y.; de Pereda, J.M.; Garc1-Alvarez, B.; Nakamoto, T.; Margolis, B.; McGlade, C.J.; Liddington, R.C.; Ginsberg, M.H. Integrin-cytoplasmic domain interactions with phosphotyrosine-binding domains: A structural prototype for diversity in integrin signaling. Proc. Natl. Acad. Sci. USA 2003, 100, 2272-2276.

68. Meves, A.; Stremmel, C.; Gottschalk, K.; Fassler, R. The Kindlin protein family: new members to the club of focal adhesion proteins. Trends Cell Biol. 2009, 19, 504-513.

69. Karakose, E.; Schiller, H.B.; Fassler, R. The kindlins at a glance. J. Cell Sci. 2010, 123, 2353-2356.

70. Harburger, D.S.; Calderwood, D.A. Integrin signalling at a glance. J. Cell Sci. 2009, 122, 159-63.

71. Bledzka, K.; Bialkowska, K.; Nie, H.; Qin, J.; Byzova, T.; Wu, C.; Plow, E.F.; Ma, Y.Q. Tyrosine phosphorylation of integrin beta3 regulates kindlin-2 binding and integrin activation. $J$. Biol. Chem. 2010, 285, 30370-30374. 
72. Ma, Y.Q.; Qin, J.; Wu, C.; Plow, E.F. Kindlin-2 (Mig-2): a co-activator of beta3 integrins. J. Cell Biol. 2008, 181, 439-46.

73. Oxley, C.L.; Anthis, N.J.; Lowe, E.D.; Vakonakis, I.; Campbell, I.D.; Wegener, K.L. An integrin phosphorylation switch: The effect of beta3 integrin tail phosphorylation on Dok1 and talin binding. J. Biol. Chem. 2008, 283, 5420-5426.

74. Saxonov, S.; Berg, P.; Brutlag, D.L. A genome-wide analysis of CpG dinucleotides in the human genome distinguishes two distinct classes of promoters. Proc. Natl. Acad. Sci. USA 2006, 103, 1412-1417.

75. Boudreau, N.J.; Varner, J.A. The homeobox transcription factor Hox D3 promotes integrin alpha5beta1 expression and function during angiogenesis. J. Biol. Chem. 2004, 279, 4862-4868.

76. Kintscher, U.; Lyon, C.; Wakino, S.; Bruemmer, D.; Feng, X.; Goetze, S.; Graf, K.; Moustakas, A.; Staels, B.; Fleck, E.; Hsueh, W.A.; Law, R.E. PPAR $\alpha$ inhibits TGF- $\beta$-induced $\beta 5$ integrin transcription in vascular smooth muscle cells by interacting with Smad4. Circ. Res. 2002, 91, e35-e44.

77. Bei, L.; Lu, Y.; Bellis, S.L.; Zhou, W.; Horvath, E.; Eklund, E.A. Identification of a HoxA10 activation domain necessary for transcription of the gene encoding beta3 integrin during myeloid differentiation. J. Biol. Chem. 2007, 282, 16846-16859.

78. Daftary, G.S.; Troy, P.J.; Bagot, C.J.; Young, S.L.; Taylor, H.S. Direct Regulation of $\beta_{3}$-Integrin Subunit Gene Expression by HOXA10 in Endometrial Cells. Mol. Endocrinol. 2002, 16, 571-579.

79. Wang, W.; Wu, W.; Desai, T.; Ward, D.C.; Kaufman, S.J. Localization of the alpha 7 integrin gene (ITGA7) on human chromosome 12q13: Clustering of integrin and Hox genes implies parallel evolution of these gene families. Genomics 1995, 26, 568-570.

80. Cao, X.; Pfaff, S.L.; Gage, F.H. A functional study of miR-124 in the developing neural tube. Gene Dev. 2007, 21, 531-536.

81. Stefani, G.; Slack, F.J. Small non-coding RNAs in animal development. Nat. Rev. Mol. Cell Biol. 2008, 9, 219-230.

82. Li, G.; Luna, C.; Qiu, J.; Epstein, D.L.; Gonzalez, P. Targeting of integrin beta1 and kinesin 2alpha by microRNA 183. J. Biol. Chem. 2010, 285, 5461-5471.

83. Mǔller, D.W.; Bosserhoff, A.K. Integrin beta 3 expression is regulated by let-7a miRNA in malignant melanoma. Oncogene 2008, 27, 6698-6706.

84. Hunt, S.; Jones, A.V.; Hinsley, E.E.; Whawell, S.A.; Lambert, D.W. MicroRNA-124 suppresses oral squamous cell carcinoma motility by targeting ITGB1. FEBS Lett. 2011, 585, 187-192.

85. Fang, L.; Deng, Z.; Shatseva, T.; Yang, J.; Peng, C.; Du, W.W.; Yee, A.J.; Ang, L.C.; He, C.; Shan, S.W.; Yang, B.B. MicroRNA miR-93 promotes tumor growth and angiogenesis by targeting integrin-beta8, Oncogene 2011, 30, 806-821.

86. Brendle, A.; Lei, H.; Brandt, A.; Johansson, R.; Enquist, K.; Henriksson, R.; Hemmink, K.; Lenner, P.; Főrstl, A. Polymorphisms in predicted microRNA-binding sites in integin genes and breast cancer: ITGB4 as prognostic marker. Carcinogenesis 2008, 29, 1394-1399.

87. Lewis, B.P.; Burge, C.B.; Bartel, D.P. Conserved seed pairing, often flanked by adenosines, indicates that thousands of human genes are microRNA targets. Cell 2005, 120, 15-20.

88. Shalgi, R.; Lieber, D.; Oren, M.; Pilpel, Y. Global and local architecture of the mammalian microRNA-transcription factor regulatory network. PLoS Comput. Biol. 2007, 3, e131. 
89. Baek, D.; Villen, J.; Shin, C.; Camargo, F.D.; Gygi, S.P. The impact of microRNAs on protein output. Nature 2008, 455, 64-71.

90. Selbach, M.; Schwanhausser, B.; Thierfelder, N.; Fang, Z.; Khanin, R. Widespread changes in protein synthesis induced by microRNAs. Nature 2008, 455, 58-63.

91. Su, A.I.; Wiltshire, T.; Batalov, S.; Lapp, H.; Ching, K.R.; Block, D.; Zhang, J.; Soden, R.; Hayakawa, M.; Kreiman, G.; Cooke, M.P.; Walker, J.R.; Hogenesch, J.B. A gene atlas of the human and mouse protein encoding transcriptomes. Proc. Natl. Acad. Sci. USA 2004, 101, 6062-6067.

92. Barczyk, M.; Carracedo, S.; Gullberg, D. Integrins. Cell Tissue Res. 2010, 339, 269-280.

93. Zhang, H.; Labouesse, M. The making of hemidesmosome structures in vivo. Dev. Dynam. 2010, 239, 1465-1476.

94. Quaranta, V. Epithelial integrins. Cell Differ. Dev. 1990, 32, 361-365.

95. Tamura, R.N.; Rozzo, C.; Starr, L.; Chambers, J.; Reichardt, L.F.; Cooper, H.M.; Quaranta, V. Epithelial integrin alpha 6 beta 4: complete primary structure of alpha 6 and variant forms of beta 4 . J. Cell Biol. 1990, 111:1593-1604.

96. Donoghue, P.C.J.; Benton, M.J. Rocks and clocks: calibrating the tree of life using fossils and molecules. Trends Genet. 2007, 22, 424-431.

97. Strunck, E.; Vollmer, G. Variants of integrin beta 4 subunit in human endometrial adenocarcinoma cells: mediators of ECM-induced differentiation? Biochem. Cell Biol. 1996, 74, 867-873.

98. Abe, M.; Sawamura, D.; Goto, M.; Nakamura, H.; Nagasaki, A.; Nomura, Y.; Kawasaki, H.; Isogai, R.; Shimizu, H. ITGB4 missense mutation in a transmembrane domain causes non-lethal variant of junctional epidermolysis bullosa with pyloric atresia. J. Dermatol. Sci. 2007, 47, 165-167.

99. Hynes, R.O. Integrins: Versatility, modulation, and signaling in cell adhesion. Cell 1992, 69, 11-25.

100. Johnson, M.S.; Lu, N.; Denessiouk, K.; Heino, J.; Gullberg, D. Integrins during evolution: evolutionary trees and model organisms. Biochim. Biophys. Acta 2009, 1788, 779-789.

101. Reddy, K.V.; Mangale, S.S. Integrin receptors: the dynamic modulators of endometrial function. Tissue Cell 2003, 35, 260-273.

102. Shapiro, L.; Love, J.; Colman, D.R. Adhesion molecules in the nervous system: structural insights into function and diversity. Annu. Rev. Neurosci. 2007, 30, 451-474.

103. Sonnenberg, A.; Calafat, J.; Janssen, H.; Daams, H.; van der Raaij-Helmer, L.M.; Falcioni, R.; Kennel, S.J.; Aplin, J.D.; Baker, J.; Loizidou, M. Integrin alpha 6/beta 4 complex is located in hemidesmosomes, suggesting a major role in epidermal cell-basement membrane adhesion. J. Cell Biol.1991, 113, 907-917.

104. Spinardi, L.; Ren, Y.L.; Sanders, R.; Giancotti, F.G. The beta 4 subunit cytoplasmic domain mediates the interaction of alpha 6 beta 4 integrin with the cytoskeleton of hemidesmosomes. Mol. Biol. Cell 1993, 4, 871-884.

105. Dowling, J.; Yu, Q.C.; Fuchs, E. Beta4 integrin is required for hemidesmosome formation, cell adhesion and cell survival. J. Cell Biol. 1996, 134, 559-572.

106. Sehgal, B.U.; DeBiase, P.J.; Matzno, S.; Chew, T.L.; Claiborne, J.N.; Hopkinson, S.B.; Russell, A.; Marinkovich, M.P.; Jones, J.C. Integrin beta4 regulates migratory behavior of keratinocytes by determining laminin-332 organization. J. Biol. Chem. 2006, 281, 35487-35498. 
107. Abedin, M.; King, N. Diverse evolutionary paths to cell adhesion. Trends Cell Biol. 2010, 20, 734-742.

108. Kim, T.H.; Kim, H.I.; Soung, Y.H.; Shaw, L.A.; Chung, J. Integrin (alpha6beta4) signals through Src to increase expression of S100A4, a metastasis-promoting factor: implications for cancer cell invasion. Mol. Canc. Res. 2009, 7, 1605-1612.

109. Nguyen, B.P.; Gil, S.G.; Carter, W.G. Deposition of laminin 5 by keratinocytes regulates integrin adhesion and signaling. J. Biol. Chem. 2000, 275, 31896-31907.

110. Miyazaki, K. Laminin-5 (laminin-332): Unique biological activity and role in tumor growth and invasion. Cancer Sci.2006, 97, 91-98.

111. Giannelli, G., Falk-Marzillier, J.; Schiraldi, O.; Stetler-Stevenson, W.G.; Quaranta, V. Induction of cell migration by matrix metalloprotease-2 cleavage of laminin-5. Science 1997, 277, 225-228.

112. Goldfinger, L.E.; Hopkinson, S.B.; deHart, G.W.; Collawn, S.; Couchman, J.R.; Jones, J.C. The alpha3 laminin subunit, alpha6beta4 and alpha3beta1 integrin coordinately regulate wound healing in cultured epithelial cells and in the skin. J. Cell Sci. 1999, 112, 2615-2629.

113. Jorgensen, C.; Couret, I.; Hellier, I.; Bologna, C.; Canovas, F.; Brochier, J.; Reme, T.; Sany, J. In vivo migration of radiolabelled lymphocytes in rheumatoid synovial tissue engrafted in SCID mice: implication of beta 2 and beta 7-integrin. J. Rheumatol. 1996, 23, 32-35.

114. Viney, J.L.; Fong, S. Beta 7 integrins and their ligands in lymphocyte migration to the gut. Chem. Immunol. 1998, 71, 64-76.

115. Lefrancois, L.; Parker, C.M.; Olson, S.; Muller, W.; Wagner, N.; Schon, M.P.; Puddington, L. The role of beta7 integrins in CD8 T cell trafficking during an antiviral immune response. J. Exp. Med. 1999, 189, 1631-1638.

116. Park, E.J.; Mora, J.R.; Carman, C.V.; Chen, J.; Sasaki, Y.; Cheng, G.; von Andrian, U.H.; Shimaoka, M. Aberrant activation of integrin alpha4beta7 suppresses lymphocyte migration to the gut. J. Clin. Investig. 2007, 117, 2526-2538.

117. Yakubenko, V.P.; Belevych, N.; Mishchuk, D.; Schurin, A.; Lam, S.C.; Ugarova, T.P. The role of integrin alpha D beta2 (CD11d/CD18) in monocyte/macrophage migration. Exp. Cell Res. 2008, 314, 2569-2578.

118. Zhu, X.; Boetticher, E.; Wang, L.; Duan, Y.; Learoyd, J.; Leff, A.R. Proline-rich tyrosine kinase 2 regulates spreading and migration of eosinophils after beta2-integrin adhesion. Am. J. Respir. Cell Mol. Biol. 2008, 39, 263-269.

119. Kelly, K.A.; Wiley, D.; Wiesmeier, E.; Briskin, M.; Butch, A.; Darville, T. The combination of the gastrointestinal integrin (alpha4beta7) and selectin ligand enhances T-Cell migration to the reproductive tract during infection with Chlamydia trachomatis. Am. J. Reprod. Immunol. Microbiol. 2009, 61, 446-452.

120. Brower, D.L.; Brower, S.M.; Hayward, D.C.; Ball, E.E. Molecular evolution of integrins: genes encoding integrin beta subunits from a coral and a sponge. Proc. Natl. Acad. Sci. USA 1997, 94, 9182-9187.

121. Humphries, M.J. Integrin activation: The link between ligand binding and signal transduction. Curr. Opin. Cell Biol. 1996, 8, 632-640. 
122. Chen, Y.Q.; Trikha, M.; Gao, X.; Bazaz, R.; Porter, A.T.; Timar, J.; Honn, K.V. Ectopic expression of platelet integrin alphaIlb beta 3 in tumor cells from various species and histological origin. Int. J. Cancer Res. 1997, 72, 642-648.

123. Moroi, M.; Jung, S.M. Integrin-mediated platelet adhesion. Front. Biosci. 1998, 3, d719-728.

124. Rout, U.K.Valproate, thalidomide and ethyl alcohol alter the migration of HTR-8/SVneo cells. Reprod. Biol. Endocrinol. 2006, 4, 44.

125. Cambi, A.; van Helden, S.F.G.; Figdor, C.G. Roles for Integrins and Associated Proteins in the Haematopoietic System. In Integrins and Development; Cambi, A., Suzanne, F.G., van Helden, C.G., Eds.; Landes Bioscience: Austin, TX, USA, 2006.

126. Burke, R.D. Invertebrate integrins: Structure, function, and evolution. Int. Rev. Cytol. 1999, 191, 257-284.

127. Altschul, F.; Vyas, V.; Cornfield, A.; Goodin, S.; Ravikumar, T.S.; Rubin, E.H.; Gupta, E. Basic local alignment search tool. J. Mol. Biol. 1997, 215, 403-410.

128. International Human Genome Sequencing Consortium. Initial sequencing and analysis of the human genome. Nature 2001, 409, 860-921.

129. Horse Genome Project. Available online: http://www.uky.edu/Ag/Horsemap/ (accessed on 21 August 2011).

130. Mouse Genome Sequencing Consortium. Initial sequencing and comparative analysis of the mouse genome. Nature 2002, 420, 520-562.

131. Mikkelsen, T.S.; Wakefield, M.J.; Aken, B.; Amemiya, C.T.; Chang, J.L.; Duke, S.; Garber, M.; Gentles, A.J.; Goodstadt, L.; Heger, A.; et al. Genome of the marsupial Monodelphis domestica reveals innovation in noncoding sequences. Nature 2007, 447, 167-175.

132. International Chicken Genome Consortium. Sequence and comparative analysis of the chicken genome provide unique perspectives on vertebrate evolution. Nature 2004, 432, 695-716.

133. Emanuelsson, O.; Brunak, S.; von Heijne, G.; Nielsen H. Locating proteins in the cell using TargetP, SignalP, and related tools. Nat. Protocol. 2007, 2, 953-971.

134. Arnold, K.; Bordoli, L.; Kopp, J.; Schwede, T. The SWISS-MODEL Workspace: A web-based environment for protein structure homology modelling. Bioinformatics 2006, 22, 195-201.

135. Vinogradova, O.; Velyvis, A.; Velyviene, A.; Hu, B.; Haas, T.; Plow, E.; Qin, J. A structural mechanism of integrin alpha(IIb)beta(3) "inside-out" activation as regulated by its cytoplasmic face. Cell 2002, 110, 587-597.

136. Abe, H.; Sasagawa, A.; Tochio, N.; Koshiba, S.; Inoue, M.; Kigawa, T.; Yokoyama, S. Solution structure of the fibronectin type III domain of human Integrin beta-4. Protein Data Bank 2011, doi: $10.2210 / \mathrm{pdb} 2 \mathrm{yrz} / \mathrm{pdb}$.

137. Hall, T.A. BioEdit: A user-friendly biological sequence alignment editor and analysis program for Windows 95/98/NT. Nucleic Acids Symp. 1999, 41, 95-99.

138. Kimura, M. The Neutral Theory of Molecular Evolution; Cambridge University Press: Cambridge, UK, 1983.

139. Van De Peer, Y.; de Wachter, R TreeCon for Windows: a software package for the construction and drawing of evolutionary trees for the Microsoft Windows environment. Comput. App. Sci. 1994, 10, 569-575. 
140. Saitou, N.; Nei, M. The neighbour-joining method: A new method for reconstructing phylogenetic trees. Mol. Biol. Evol. 1987, 4, 406-411.

141. Felsenstein, J. Confidence limits on phylogenies: an approach using the bootstrap. Evolution 1985, 39, 783-789

(C) 2011 by the authors; licensee MDPI, Basel, Switzerland. This article is an open access article distributed under the terms and conditions of the Creative Commons Attribution license (http://creativecommons.org/licenses/by/3.0/). 